\title{
Contrasting roles of interception and transpiration in the hydrological cycle - Part 2: Moisture recycling
}

\author{
R. J. van der Ent ${ }^{1}$, L. Wang-Erlandsson ${ }^{1,2}$, P. W. Keys ${ }^{2,3}$, and H. H. G. Savenije ${ }^{1}$ \\ ${ }^{1}$ Department of Water Management, Faculty of Civil Engineering and Geosciences, \\ Delft University of Technology, Delft, the Netherlands \\ ${ }^{2}$ Stockholm Resilience Centre, Stockholm University, Stockholm, Sweden \\ ${ }^{3}$ Department of Atmospheric Science, Colorado State University, Fort Collins, USA \\ Correspondence to: R. J. van der Ent (r.j.vanderent@tudelft.nl) \\ Received: 25 February 2014 - Published in Earth Syst. Dynam. Discuss.: 14 March 2014 \\ Revised: 29 July 2014 - Accepted: 18 August 2014 - Published: 5 December 2014
}

\begin{abstract}
The contribution of land evaporation to local and remote precipitation (i.e. moisture recycling) is of significant importance to sustain water resources and ecosystems. But how important are different evaporation components in sustaining precipitation? This is the first paper to present moisture recycling metrics for partitioned evaporation. In the companion paper Wang-Erlandsson et al. (2014) (hereafter Part 1), evaporation was partitioned into vegetation interception, floor interception, soil moisture evaporation and open-water evaporation (constituting the direct, purely physical fluxes, largely dominated by interception), and transpiration (delayed, biophysical flux). Here, we track these components forward as well as backward in time. We also include age tracers to study the atmospheric residence times of these evaporation components. We present a new image of the global hydrological cycle that includes quantification of partitioned evaporation and moisture recycling as well as the atmospheric residence times of all fluxes. We demonstrate that evaporated interception is more likely to return as precipitation on land than transpired water. On average, direct evaporation (essentially interception) is found to have an atmospheric residence time of 8 days, while transpiration typically resides for 9 days in the atmosphere. The process scale over which evaporation recycles is more local for interception compared to transpiration; thus interception generally precipitates closer to its evaporative source than transpiration, which is particularly pronounced outside the tropics. We conclude that interception mainly works as an intensifier of the local hydrological cycle during wet spells and wet seasons. On the other hand, transpiration remains active during dry spells and dry seasons and is transported over much larger distances downwind, where it can act as a significant source of moisture. Thus, as various land-use types can differ considerably in their partitioning between interception and transpiration, our results stress that land-use changes (e.g. forest-to-cropland conversion) do not only affect the magnitude of moisture recycling, but could also influence the moisture recycling patterns and lead to a redistribution of water resources. As such, this research highlights that land-use changes can have complex effects on the atmospheric branch of the hydrological cycle.
\end{abstract}

\section{Introduction}

It is challenging to gain improved understanding of the different mechanisms that drive land-atmospheric interaction. One of these mechanisms is the contribution of terrestrial evaporation to local and remote precipitation (i.e. moisture recycling). Early studies have used analytical methods to estimate the amount of precipitation that recycles within a basin or area of interest (see e.g. Lettau et al., 1979; Brubaker et al., 1993; Eltahir and Bras, 1994; Savenije, 1995; Burde and Zangvil, 2001). However, this field of study has advanced much with the introduction of atmospheric moisture tracking methods to estimate moisture recycling (e.g. Koster et al., 1986; Dirmeyer and Brubaker, 1999; Bosilovich and Schubert, 2002). 
Several studies have shown global maps of continental precipitation recycling, indicating that about $40 \%$ of the continental precipitation is of continental origin, but this number is much higher in, e.g., China (Bosilovich et al., 2002; Yoshimura et al., 2004; van der Ent et al., 2010; Goessling and Reick, 2011, 2013). Numaguti (1999) included a wide variety of moisture tracers into a general circulation model (GCM) to track water and its age through the atmosphere as well as through the soil. It was found, for example, that, counting from the moment of evaporation from the ocean, the mean water age of precipitating water in north-eastern Asia could exceed half a year whereby a water particle had been recycled on average twice. A comprehensive overview and quantification of import and export of water vapour between countries was given by Dirmeyer et al. (2009).

While nearly all previous studies focused on the "recycled" part of precipitation, van der Ent et al. (2010) also focused on the recycled part of evaporation. They, for example, found that in evaporation recycling "hot spots" such as eastern Africa and the northern Amazon about 60 to $90 \%$ of the evaporation returns as continental precipitation. When it comes to moisture recycling as a metric for local landatmosphere coupling, the follow-up study of van der Ent and Savenije (2011) solved the problem of scale and shape dependency of the regional moisture recycling ratios by converting these to length scales of the recycling process (average travel distances under local conditions). They showed that in the tropics and in mountainous terrain these length scales can be as low as 500 to $2000 \mathrm{~km}$. Spatially distributed global maps of actual average travel distances to precipitation were given by Dirmeyer et al. (2014).

Partly these findings will be due to a passive role of moisture in the hydrological cycle (e.g. Goessling and Reick, 2011), but it is also suggested by the results of other studies that less (more) evaporated moisture actively leads to a decrease (increase) in precipitation (e.g. Dekker et al., 2007; Spracklen et al., 2012; Rios-Entenza and Miguez-Macho, 2013). Therefore, moisture recycling is believed to be of significant importance for water resources, agriculture, and ecosystems. Some studies have looked specifically at these issues. For instance, Dominguez and Kumar (2008) studied the central United States plains and concluded that local evaporative fluxes ensure ecoclimatological stability through a continued moisture contribution when advective fluxes diminish. Another example of ecosystem importance is the study by Spracklen et al. (2012), who found that air passing over dense vegetation produces much more rain than air passing over sparse vegetation. Regarding agriculture, Bagley et al. (2012) reported that reduced moisture recycling due to land-cover change may lead to potential crop yield reductions of 1 to $17 \%$ in the world's breadbasket regions, while other studies have looked at the positive effect of irrigation in increasing moisture recycling (e.g. Tuinenburg et al., 2012; Wei et al., 2012). Considering moisture recycling as something that could potentially be managed, Keys et al. (2012) proposed the concept of the precipitationshed as a tool to assess the vulnerability of a certain region to land-use changes in its moisture-contributing regions.

Land-use changes change not only total evaporation but also its partitioning into its direct and delayed components. It is therefore somewhat surprising that all moisture recycling studies have reported their results in terms of moisture recycling due to total evaporation only. It has been speculated, however, that interception (direct evaporation) and transpiration (delayed evaporation) are likely to play a different role in moisture recycling (Savenije, 2004). This has, however, never been quantified. A possible method would be to try to link stable water isotope measurements to moisture recycling (e.g. Kurita et al., 2004; Tian et al., 2007; Risi et al., 2013). Gat and Matsui (1991) used the deuterium excess (dexcess) value of stable water isotopes to estimate that 20 $40 \%$ of the evaporative flux in the Amazon basin is fractionating the isotopic composition. Theoretically, d-excess values in precipitation from for example the Global Network of Isotopes in Precipitation (GNIP) database (Froehlich et al., 2001) could be combined with estimates of moisture recycling (e.g. van der Ent and Savenije, 2011) to infer the contributions of fractionating and non-fractionating evaporation. However, the spatial and temporal resolution of available isotopic data is rather limited. Another difficulty is the fact that, while it is generally accepted that open-water evaporation is fractionating and evaporation of transpired water is not, for vegetation interception and floor interception the extent of fractionation is less clear (e.g. Gat and Matsui, 1991; Henderson-Sellers et al., 2002).

Global land-surface models generally include a partitioning of terrestrial evaporation into several direct and delayed components. These components include evaporation from transpiration, vegetation interception, floor interception, soil moisture, and open water, although the names and exact definitions of these terms can differ from model to model. In any case, information on these individual components is not often reported and data are generally not provided (e.g. Mueller et al., 2013). This is probably the reason that, to our knowledge, no studies applying numerical atmospheric moisture tracking (see Gimeno et al., 2012; van der Ent et al., 2013) have considered the different components of terrestrial evaporation separately. In order to obtain a tailor-made data set of partitioned evaporation, Wang-Erlandsson et al. (2014), the companion paper, hereafter referred to as Part 1, developed STEAM (Simple Terrestrial Evaporation to Atmosphere Model). This is a global hydrological land-surface model, which is specifically focused on realistic estimations of partitioned evaporation and how this depends on vegetation and land use.

The goal of this paper is to investigate and quantify the importance of the different components of evaporation in the hydrological cycle over continents. We aim to present a new image of the global hydrological cycle which includes quantification of partitioned evaporation and moisture recycling 
as well as the atmospheric residence times of the individual components. Furthermore, we aim to provide spatially distributed global maps of different moisture recycling metrics that describe the role of interception and transpiration for local and remote moisture recycling processes in time and space. This provides new information on the susceptibility of regions to land-use changes. For example, if region A receives precipitation from transpiration in region B's dry season, then region A may experience increased dryness if region $\mathrm{B}$ were to be desertified.

\section{Methods}

\subsection{Data}

The input data for our atmospheric moisture tracking model, WAM-2layers (Water Accounting Model-2 layers) (see Appendix A), come from STEAM (Part 1) and the ERA-Interim reanalysis (ERA-I) (Dee et al., 2011). STEAM evaporation data are also based on ERA-I (see Part 1 for details). The output of STEAM is the total evaporation $E$ over all terrestrial areas partitioned into five components:

$$
\begin{aligned}
E & =E_{\text {vegetation_interception }}+E_{\text {floorinterception }}+E_{\text {soil_moisture }} \\
& +E_{\text {inland_waters }}+E_{\text {transpiration }} .
\end{aligned}
$$

Vegetation interception is all water that is intercepted by the leaves, branches, and stems of vegetation. We define floor interception as all water that is intercepted by the ground and litter surface. Soil moisture evaporation is physical evaporation from the unsaturated zone. Transpiration is water that evaporates from the stomata of leaves and draws from the unsaturated zone as well (see Part 1 for details). In this paper we combine the direct (purely physical) evaporative fluxes into one term $E_{\mathrm{i}}$, containing evaporation from interception, soil moisture, and inland waters:

$$
\begin{aligned}
E_{i} & =E_{\text {vegetation_interception }}+E_{\text {floorinnterception }}+E_{\text {soil_moisture }} \\
& +E_{\text {inland_waters. }} .
\end{aligned}
$$

This term consists of the direct fluxes from vegetation interception, floor interception, and soil moisture evaporation, which have a small storage reservoir and short residence time at the surface (Part 1, Figs. 9 and 10). As the relative global contribution from the soil moisture and inland waters is quite small (Part 1, Fig. 2), this term mainly represents interception, but regionally other components can dominate. Transpiration, the delayed (biophysical) evaporative flux, on the other hand, provides a slow feedback with a large storage reservoir, which is the other component that we track:

$E_{\mathrm{t}}=E_{\text {transpiration }}$.

From ERA-I we use precipitation and evaporation over the oceans. For the terrestrial evaporation we use the partitioned evaporation fluxes computed by STEAM (forced by ERA-I; see Part 1). Furthermore, we use specific humidity and zonal and meridional wind speed from ERA-I. We downloaded these data at model levels spanning the atmosphere from zero pressure to surface pressure. Surface fluxes were downloaded at 3-hourly intervals and the other data at 6-hourly intervals. The data we use are on a $1.5^{\circ}$ latitude $\times 1.5^{\circ}$ longitude grid and cover the period of 1998-2009, but the results are presented for 1999-2008, because we use 1 year as model spin-up for both the backward and forward tracking. In Appendix A we show annual average, as well as January and July figures for precipitation, direct evaporative fluxes (interception), and the delayed evaporative flux (transpiration). Appendix B contains further details about the moisture tracking in WAM-2layers.

We consider STEAM and ERA-I as adequate data sources to perform realistic moisture tracking, and their global estimates of evaporation and precipitation fall well within the range of estimates given by other studies. It was shown that ERA-I performs better in reproducing the hydrological cycle than ERA-40 (Trenberth et al., 2011) and even performs better in terms of water balance closure than the other reanalysis products MERRA (Modern-Era Retrospective Analysis for Research and Applications) and CFSR (Climate Forecast System Reanalysis) (Lorenz and Kunstmann, 2012). Keys et al. (2014) used both ERA-I and MERRA as inputs for WAM-2layers and showed that global moisture recycling patterns are not very different. However, it should be clear that the moisture recycling metrics presented in Sect. 3 are in fact dependent on the input data. In Sect. 3.6 we investigate the robustness of our main results.

\subsection{Definitions of moisture recycling metrics}

Here, we define moisture recycling metrics, each of which contains different information about the moisture recycling process. First, we start with the metrics related to continental moisture recycling, which are measures for land-atmosphere coupling at continental scale. Second, we define metrics related to the timescale of the moisture recycling process. Finally, we define metrics that act as measure for local moisture feedback.

\subsubsection{Continental moisture recycling}

In the context of continental moisture recycling (see also van der Ent et al., 2010), precipitation on land $P$ can be separated as follows:

$P=P_{\mathrm{o}}+P_{\mathrm{c}}=P_{\mathrm{o}}+P_{\mathrm{c}, \mathrm{i}}+P_{\mathrm{c}, \mathrm{t}}$,

where $P_{\mathrm{o}}$ is the part that is of oceanic origin and $P_{\mathrm{c}}$ is the continentally recycled part of the precipitation (i.e. most recently evaporated from a continental area). $P_{\mathrm{c}}$ can be split further into $P_{\mathrm{c}, \mathrm{i}}$ (i.e. the recycled precipitation that originates from vegetation interception, floor interception, soil moisture and inland waters) and $P_{\mathrm{c}, \mathrm{t}}$ (i.e. the recycled precipitation that 
originates from transpiration). The "continental precipitation recycling ratio for interception" is defined as

$\rho_{\mathrm{c}, \mathrm{i}}=P_{\mathrm{c}, \mathrm{i}} / P$

and the "continental precipitation recycling ratio for transpiration" as

$\rho_{\mathrm{c}, \mathrm{t}}=P_{\mathrm{c}, \mathrm{t}} / P$.

Also in the context of continental moisture recycling, we split land evaporation $E$ :

$E=E_{\mathrm{o}}+E_{\mathrm{c}}=E_{\mathrm{o}, \mathrm{i}}+E_{\mathrm{o}, \mathrm{t}}+E_{\mathrm{c}, \mathrm{i}}+E_{\mathrm{c}, \mathrm{t}}$,

where $E_{\mathrm{o}}$ is the part of the evaporation that precipitates on the ocean and $E_{\mathrm{c}}$ is the continental recycling part (i.e. returns as continental precipitation). Subscripts $i$ and $t$ denote the interception (Eq. 2) and transpiration (Eq. 3) respectively. It also holds that $E_{\mathrm{i}}=E_{\mathrm{o}, \mathrm{i}}+E_{\mathrm{c}, \mathrm{i}}$ and that $E_{\mathrm{t}}=E_{\mathrm{o}, \mathrm{t}}+E_{\mathrm{c}, \mathrm{t}}$. This also allows us to define the "continental evaporation recycling ratio for interception" as

$\varepsilon_{\mathrm{c}, \mathrm{i}}=E_{\mathrm{c}, \mathrm{i}} / E$

and the "continental evaporation recycling ratio for transpiration" as

$\varepsilon_{\mathrm{c}, \mathrm{t}}=E_{\mathrm{c}, \mathrm{t}} / E$.

The two metrics in Eqs. (8) and (9) both carry information about their relative contribution to moisture recycling as well as their relative contribution to total evaporation. To study the recycling efficiency of the individual partitioned fluxes, we define the "continental evaporation recycling efficiency for interception" as

$\varepsilon_{\mathrm{c}, \mathrm{ii}}=E_{\mathrm{c}, \mathrm{i}} / E_{\mathrm{i}}$

and the "continental evaporation recycling efficiency for transpiration" as

$\varepsilon_{\mathrm{c}, \mathrm{tt}}=E_{\mathrm{c}, \mathrm{t}} / E_{\mathrm{t}}$.

\subsubsection{Atmospheric lifetime of recycled moisture}

Previous studies by Trenberth (1998) and by van der Ent and Savenije (2011) calculated the local depletion and restoration timescales of atmospheric moisture, defined as the atmospheric moisture storage over precipitation and evaporation respectively. Trenberth (1998) estimated the average timescale over land to be around 9 days. However meaningful, these timescales only provided local information; they did not indicate the actual time spent in the atmosphere by a recycled water particle. Therefore, we propose new metrics that describe the actual time spent in the atmospheric. We define the "lifetime of continentally recycled precipitation":

$\tau_{\rho, \mathrm{c}}=N\left(P_{\mathrm{c}} \leftarrow E_{\mathrm{c}}\right)$, where $N$ stands for the time spent in the atmosphere, or, in other words, the age of the water particle. The lifetime of continentally recycled precipitation $\tau_{\rho, \mathrm{c}}$ is a measure at the point where a water particle precipitates and stands for the average time spent between continental evaporation and continental precipitation, or, in other words, the average age at the point where a water particle precipitates. Note that $\tau_{\rho, \mathrm{c}}$ only provides information on the recycled part of the precipitation and not on the total precipitation (see Eq. 4). Likewise we define the "lifetime of the interception that recycles on land" as

$\tau_{\varepsilon, \mathrm{c}, \mathrm{i}}=N\left(E_{\mathrm{c}, \mathrm{i}} \rightarrow P_{\mathrm{c}, \mathrm{i}}\right)$

and the "lifetime of the transpiration that recycles on land" as

$\tau_{\varepsilon, \mathrm{c}, \mathrm{t}}=N\left(E_{\mathrm{c}, \mathrm{t}} \rightarrow P_{\mathrm{c}, \mathrm{t}}\right)$.

Both metrics in Eqs. (13) and (14) are defined at the place where evaporation occurs at the land surface $\left(E_{\mathrm{c}}\right.$ in Eq. 7) and determine the average time an evaporated water particle that returns as precipitation on land will spend in the atmosphere. For the calculation of these lifetimes we included water age tracers in our model (Appendix B3).

\subsubsection{Local recycling and the length scales of evaporated water}

Besides the continental recycling metrics, we are also interested in the feedback between evaporation and precipitation locally. For a certain predefined region (e.g. a grid cell) we can split precipitation and evaporation as follows:

$P=P_{\mathrm{a}}+P_{\mathrm{r}}=P_{\mathrm{a}, \mathrm{i}}+P_{\mathrm{a}, \mathrm{t}}+P_{\mathrm{r}, \mathrm{i}}+P_{\mathrm{r}, \mathrm{t}}$

and

$E=E_{\mathrm{a}}+E_{\mathrm{r}}=E_{\mathrm{a}, \mathrm{i}}+E_{\mathrm{a}, \mathrm{t}}+E_{\mathrm{r}, \mathrm{i}}+E_{\mathrm{r}, \mathrm{t}}$,

where $P_{\mathrm{a}}$ is the part of the precipitation that comes from moisture advected into the region, $E_{\mathrm{a}}$ is the part of the evaporation that is advected away from the grid cell, and $P_{\mathrm{r}}$ and $E_{\mathrm{r}}$ are the regional recycling parts (i.e. recycle within the same region). Subscripts i and t again denote interception (Eq. 2) and transpiration (Eq. 3) respectively. This also allows us to define the "regional precipitation recycling ratio" as

$\rho_{\mathrm{r}}=P_{\mathrm{r}} / P$

and the "regional evaporation recycling ratio" as

$\varepsilon_{\mathrm{r}}=E_{\mathrm{r}} / E$.

We should realise that these ratios are scale- and shapedependent, which is problematic as grid cells generally differ in scale and shape. Some studies have tried to overcome this problem by scaling such ratios to a common reference area 
(e.g. Trenberth, 1999; Dominguez et al., 2006; Dirmeyer and Brubaker, 2007). However, such an approach fails to properly take into account the shape of the region and the orientation of the prevailing winds.

As an alternative, van der Ent and Savenije (2011) developed a method that yields scale- and shape-independent measures for local evaporation-precipitation interaction. Suppose we are following an atmospheric water particle along a streamline in the same direction as the wind direction. The streamline starts in point $X_{0}$ and ends in point $X_{1}$, and the distance between $X_{0}$ and $X_{1}$ is $\Delta x$. Based on Dominguez et al. (2006) and van der Ent and Savenije (2011), we can write

$\rho_{X_{1}}(\Delta x)=1-\left(\exp \left(-\Delta x / \lambda_{\rho}\right)\right)$

and

$\varepsilon_{X_{0}}(\Delta x)=1-\left(\exp \left(-\Delta x / \lambda_{\varepsilon}\right)\right)$,

where $\rho_{X_{1}}$ is the precipitation recycling ratio in $X_{1}$ and $\varepsilon_{X_{0}}$ is the evaporation recycling ratio in $X_{0}$ (i.e. the fraction of evaporation in $X_{0}$ that returns as precipitation to the land surface along the streamline). $\lambda_{\rho}$ represents the "local length scale of precipitation recycling",

$\lambda_{\rho}=\frac{S u_{\mathrm{h}}}{E}$,

and $\lambda_{\varepsilon}$ is the "local length scale of evaporation recycling":

$\lambda_{\varepsilon}=\frac{S u_{\mathrm{h}}}{P}$,

where $S$ is atmospheric moisture storage (i.e. precipitable water) and $u_{\mathrm{h}}$ is horizontal wind speed. These length scales $\lambda$ have dimension length $[\mathrm{L}]$ and can be physically interpreted as the average travel distances before precipitation if $\frac{S u_{\mathrm{h}}}{E}$ is constant upwind, or as the average travel distance after evaporation if $\frac{S u_{\mathrm{h}}}{P}$ remains equal downwind. However, it is generally unlikely for these quantities to remain equal over a large distance, so $\lambda$ must be interpreted as the local process scale of recycling. When we consider the distance $\Delta x$ to be sufficiently small, we can also obtain the areal average regional precipitation recycling ratio (Eq. 17) by integrating Eq. (19), dividing by the distance and substituting Eq. (21):

$\rho_{\mathrm{r}}=\frac{\Delta x+\lambda_{\rho} \exp \left(-\frac{\Delta x}{\lambda_{\rho}}\right)-\lambda_{\rho}}{\Delta x}$.

The exact solution for $\lambda_{\rho}$ is

$\lambda_{\rho}=\frac{\Delta x}{W\left(\frac{\exp \left(\frac{1}{\rho_{\mathrm{r}}-1}\right)}{\rho_{\mathrm{r}}-1}\right)+\frac{1}{1-\rho_{\mathrm{r}}}}$,

where $W(a)$ is the Lambert $W$ function (e.g. Corless et al., 1996). In this research, however, we are interested in the local length scale for interception and transpiration recycling. Using the fluxes in Eq. (16), we first define the "regional evaporation recycling efficiency for interception" as

$\varepsilon_{\mathrm{r}, \mathrm{ii}}=E_{\mathrm{r}, \mathrm{i}} / E_{\mathrm{i}}$

and the "regional evaporation recycling efficiency for transpiration" as

$\varepsilon_{\mathrm{r}, \mathrm{tt}}=E_{\mathrm{r}, \mathrm{t}} / E_{\mathrm{t}}$.

Analogous to Eqs. (23) and (24), the "local length scale of evaporation recycling for interception" can be found by

$\lambda_{\varepsilon, \mathrm{i}}=\frac{\Delta x}{W\left(\frac{\exp \left(\frac{1}{\varepsilon_{\mathrm{r}, \mathrm{ii}}-1}\right)}{\varepsilon_{\mathrm{r}, \mathrm{i}}-1}\right)+\frac{1}{1-\varepsilon_{\mathrm{r}, \mathrm{ii}}}}$,

and the "local length scale of evaporation recycling for transpiration" can be found by

$\lambda_{\varepsilon, \mathrm{t}}=\frac{\Delta x}{W\left(\frac{\exp \left(\frac{1}{\varepsilon_{\mathrm{r}, \mathrm{tt}}-1}\right)}{\varepsilon_{\mathrm{r}, \mathrm{t}}-1}\right)+\frac{1}{1-\varepsilon_{\mathrm{r}, \mathrm{tt}}}}$.

Note that both $\lambda_{\varepsilon, \mathrm{i}}$ and $\lambda_{\varepsilon, \mathrm{t}}$ are defined by $\frac{S u_{\mathrm{h}}}{P}$ (Eq. 22), so they are only equal if evaporation from interception and transpiration occur simultaneously. However, in many cases they will occur at different times when the quantity $\frac{S u_{\mathrm{h}}}{P}$ is different. As a result, $\lambda_{\varepsilon, \mathrm{i}}$ and $\lambda_{\varepsilon, \mathrm{t}}$ are likely to have different values and can be effectively used in revealing their relative importance for local moisture feedback. In Appendix B4 it is explained how the variable inputs in Eqs. (24), (27), and (28) were obtained in this study. Table 1 provides an overview of all metrics used in this paper.

\section{Results and discussion}

\subsection{New image of the hydrological cycle over land}

Figure 1 presents an image of the global hydrological cycle over land. In contrast to traditional images of the hydrological cycle (e.g. Chahine, 1992), we include a quantification of moisture recycling, partitioned evaporation, and the lifetime of all these components separately. Before precipitation falls on land, its average atmospheric residence time is about 10 days. We estimate that about $38 \%$ of continental precipitation $P$ is transformed into runoff $Q$, and the remaining part evaporates by direct (purely physical) fluxes $E_{\mathrm{i}}$ and by the delayed (biophysical) flux $E_{\mathrm{t}}$ (see Part 1). A portion of this land evaporation is advected to the oceans and precipitates there $E_{\mathrm{o}}$. The remaining part recycles over land, but, interestingly, interception $E_{\mathrm{c}, \mathrm{i}}$ and transpiration $E_{\mathrm{c}, \mathrm{t}}$ do so in different relative magnitudes. Of interception, $60 \%\left(E_{\mathrm{c}, \mathrm{i}} / E_{\mathrm{i}}\right)$ recycles, while transpiration recycles slightly less at $56 \%$ $\left(E_{\mathrm{c}, \mathrm{t}} / E_{\mathrm{t}}\right)$. The lifetime in the atmosphere of evaporated water 
Table 1. Overview of moisture recycling metrics used in this study.

\begin{tabular}{|c|c|c|c|c|}
\hline Moisture recycling metric & Symbol & Formula(s) & Meaning & Figures \\
\hline \multicolumn{5}{|l|}{ Continental moisture recycling metrics } \\
\hline Continental precipitation recycling ratio & $\rho_{\mathrm{c}}$ & $P_{\mathrm{c}} / P$ & Fraction of $P$ that comes from terrestrial $E$ & $2 \mathrm{a}$ \\
\hline $\begin{array}{l}\text { Continental precipitation recycling ratio } \\
\text { for interception }\end{array}$ & $\rho_{\mathrm{c}, \mathrm{i}}$ & $P_{\mathrm{c}, \mathrm{i}} / P$ & Fraction of $P$ that comes from $E_{\mathrm{i}}$ & $2 b, 6 a, 6 b$ \\
\hline $\begin{array}{l}\text { Continental precipitation recycling ratio } \\
\text { for transpiration }\end{array}$ & $\rho_{\mathrm{c}, \mathrm{t}}$ & $P_{\mathrm{c}, \mathrm{t}} / P$ & Fraction of $P$ that comes from $E_{\mathrm{t}}$ & $2 \mathrm{c}, 6 \mathrm{c}, 6 \mathrm{~d}$ \\
\hline Continental evaporation recycling ratio & $\varepsilon_{\mathrm{c}}$ & $E_{\mathrm{c}} / E$ & Fraction of $E$ that returns as terrestrial $P$ & $3 e$ \\
\hline $\begin{array}{l}\text { Continental evaporation recycling ratio } \\
\text { for interception }\end{array}$ & $\varepsilon_{\mathrm{c}, \mathrm{i}}$ & $E_{\mathrm{c}, \mathrm{i}} / E$ & $\begin{array}{l}\text { Fraction of } E \text { that is interception } \\
\text { which returns as terrestrial } P\end{array}$ & $3 \mathrm{a}$ \\
\hline $\begin{array}{l}\text { Continental evaporation recycling efficiency } \\
\text { for interception }\end{array}$ & $\varepsilon_{\mathrm{c}, \mathrm{ii}}$ & $E_{\mathrm{c}, \mathrm{i}} / E_{\mathrm{i}}$ & Fraction of $E_{\mathrm{i}}$ that returns as terrestrial $P$ & $3 b$ \\
\hline $\begin{array}{l}\text { Continental evaporation recycling ratio } \\
\text { for transpiration }\end{array}$ & $\varepsilon_{\mathrm{c}, \mathrm{t}}$ & $E_{\mathrm{c}, \mathrm{t}} / E$ & $\begin{array}{l}\text { Fraction of } E \text { that is transpiration } \\
\text { which returns as terrestrial } P\end{array}$ & $3 \mathrm{c}$ \\
\hline $\begin{array}{l}\text { Continental evaporation recycling efficiency } \\
\text { for transpiration }\end{array}$ & $\varepsilon_{\mathrm{c}, \mathrm{tt}}$ & $E_{\mathrm{c}, \mathrm{t}} / E_{\mathrm{t}}$ & Fraction of $E_{\mathrm{t}}$ that returns as terrestrial $P$ & $3 \mathrm{~d}$ \\
\hline Lifetime of continentally recycled precipitation & $\tau_{\rho, \mathrm{c}}$ & $N\left(P_{\mathrm{c}} \leftarrow E_{\mathrm{c}}\right)$ & Time spent in the atmosphere by $P_{\mathrm{c}}$ & $4 \mathrm{a}$ \\
\hline Lifetime of the interception that recycles on land & $\tau_{\varepsilon, \mathrm{c}, \mathrm{i}}$ & $N\left(E_{\mathrm{c}, \mathrm{i}} \rightarrow P_{\mathrm{c}, \mathrm{i}}\right)$ & Time $E_{\mathrm{c}, \mathrm{i}}$ spends in the atmosphere & $4 b, 6 e, 6 f$ \\
\hline Lifetime of the transpiration that recycles on land & $\tau_{\varepsilon, \mathrm{c}, \mathrm{t}}$ & $N\left(E_{\mathrm{c}, \mathrm{i}} \rightarrow P_{\mathrm{c}, \mathrm{i}}\right)$ & Time $E_{\mathrm{c}, \mathrm{t}}$ spends in the atmosphere & $4 \mathrm{c}, 6 \mathrm{~g}, 6 \mathrm{~h}$ \\
\hline \multicolumn{5}{|l|}{ Regional/local moisture recycling metrics } \\
\hline Regional precipitation recycling ratio & $\rho_{\mathrm{r}}$ & $P_{\mathrm{r}} / P$ & $\begin{array}{l}\text { Fraction of } P \text { that comes from } E \\
\text { in the same region }\end{array}$ & - \\
\hline Regional evaporation recycling ratio & $\varepsilon_{\mathrm{r}}$ & $E_{\mathrm{r}} / E$ & $\begin{array}{l}\text { Fraction of } E \text { that returns as } P \\
\text { in the same region }\end{array}$ & - \\
\hline $\begin{array}{l}\text { Regional evaporation recycling efficiency } \\
\text { for interception }\end{array}$ & $\varepsilon_{\mathrm{r}, \mathrm{ii}}$ & $E_{\mathrm{r}, \mathrm{i}} / E_{\mathrm{i}}$ & $\begin{array}{l}\text { Fraction of } E_{\mathrm{i}} \text { that returns as } P \\
\text { in the same region }\end{array}$ & - \\
\hline $\begin{array}{l}\text { Regional evaporation recycling efficiency } \\
\text { for transpiration }\end{array}$ & $\varepsilon_{\mathrm{r}, \mathrm{tt}}$ & $E_{\mathrm{r}, \mathrm{t}} / E_{\mathrm{t}}$ & $\begin{array}{l}\text { Fraction of } E_{\mathrm{t}} \text { that returns as } P \\
\text { in the same region }\end{array}$ & - \\
\hline Length scale of precipitation recycling & $\lambda_{\rho}$ & $\begin{array}{l}S u_{\mathrm{h}} / E, \\
\frac{\Delta x}{W\left(\frac{\exp \left(\frac{1}{\rho_{\mathrm{r}}-1}\right)}{\rho_{\mathrm{r}}-1}\right)+\frac{1}{1-\rho_{\mathrm{r}}}}\end{array}$ & $\begin{array}{l}\text { Atmospheric travel distance of } P \\
\text { under local conditions* }\end{array}$ & $4 \mathrm{a}$ \\
\hline $\begin{array}{l}\text { Length scale of evaporation recycling } \\
\text { for interception }\end{array}$ & $\lambda_{\varepsilon, \mathrm{i}}$ & $\frac{S u_{\mathrm{h}} / P,}{W\left(\frac{\exp \left(\frac{1}{\varepsilon_{\mathrm{r}, \mathrm{ii}}-1}\right)}{\varepsilon_{\mathrm{rii}}-1}\right)+\frac{1}{1-\varepsilon_{\mathrm{r}, \mathrm{ii}}}}$ & $\begin{array}{l}\text { Atmospheric travel distance of } E_{\mathrm{i}} \\
\text { under local conditions* }\end{array}$ & $4 b, 6 i, 6 j$ \\
\hline $\begin{array}{l}\text { Length scale of evaporation recycling } \\
\text { for transpiration }\end{array}$ & $\lambda_{\varepsilon, \mathrm{t}}$ & $\frac{S u_{\mathrm{h}} / P,}{W\left(\frac{\exp \left(\frac{1}{\varepsilon_{\mathrm{r}, \mathrm{tt}}-1}\right)}{\varepsilon_{\mathrm{r}, \mathrm{t}}-1}\right)+\frac{1}{1-\varepsilon_{\mathrm{r}, \mathrm{tt}}}}$ & $\begin{array}{l}\text { Atmospheric travel distance of } E_{\mathrm{t}} \\
\text { under local conditions* }\end{array}$ & $4 \mathrm{c}, 6 \mathrm{k}, 6 \mathrm{l}$ \\
\hline
\end{tabular}

* Note that this is not an actual travel distance, but an indication of the local intensity of the hydrological cycle.

is on average more than a week, which is similar to a previous estimate of 9.2 days (Bosilovich et al., 2002). The recycled part of evaporation, however, spends on average less than a week in the atmosphere. We can also observe that (the recycled part of) interception has a shorter lifetime in the atmosphere. Finally, global continental precipitation recycling $P_{\mathrm{c}}$ is estimated at $36 \%$, slightly less than the $40 \%$ estimated in a previous study using WAM-1layer and ERA-I evaporation (van der Ent et al., 2010). This is mainly caused by the other forcing data, STEAM instead of ERA-Interim, but about $0.5 \%$ is due to the inclusion of the second layer in WAM-2layers. Averaged globally, the recycling efficiencies and atmospheric lifetimes are not very different for interception and transpiration, but locally these differences can be large, which we show in Sects. 3.2 to 3.6, where we discuss the spatial patterns of the magnitudes and timescales of the recycling fluxes in the hydrological cycle.

\subsection{Continental moisture recycling}

Figure 2 shows the annual average continental precipitation recycling ratios for total evaporation (Fig. 2a), for interception (Eq. 5 and Fig. 2b), and transpiration (Eq. 6 and Fig. 2c). While interpreting the figure, it should be remembered that "interception" includes evaporation from the vegetation, floor, soil, and inland waters (Eq. 2). The areas that depend heavily on continental precipitation recycling are potentially susceptible to (upwind) changes in land use. Animations 1 to 3 (Supplement) illustrate how we obtained Fig. 2 with forward tracking runs of tagged terrestrial evaporation, 


\begin{tabular}{|l|}
\hline Water origin: \\
Oceanic \\
Vegetation \\
interception + \\
floor interception \\
+ soil moisture \\
+ inland waters \\
$\quad$ Transpiration \\
Black numbers \\
indicate the \\
magnitude of the \\
flux relative to \\
total continental \\
precipitation (\%). \\
Red numbers \\
indicate the \\
average \\
atmospheric \\
lifetime (days). \\
\hline
\end{tabular}

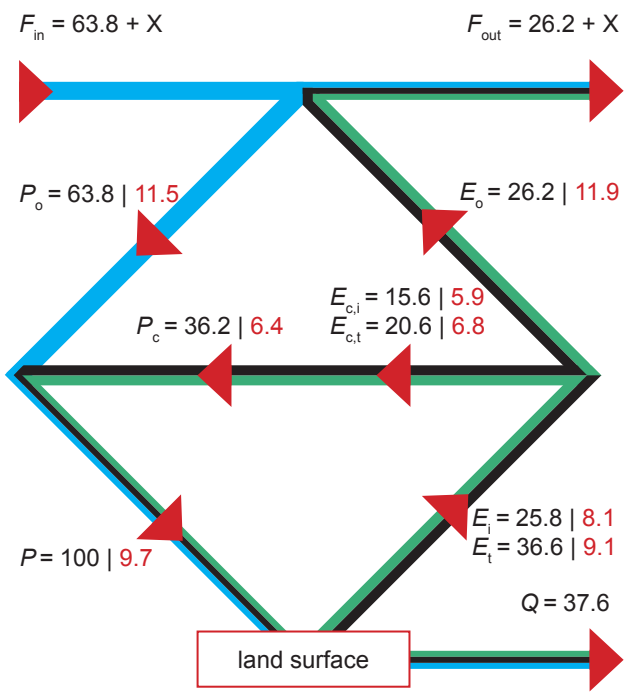

Figure 1. Global hydrological cycle over land, i.e. all continents considered together (1999-2008). $F_{\text {in }}$ is the atmospheric moisture of oceanic origin that crosses the ocean-land boundary and enters the atmosphere above land. $F_{\text {out }}$ is the atmospheric moisture that leaves the ocean-land boundary towards the ocean. Thus, $\mathrm{X}$ represents the atmospheric moisture of oceanic origin that passes through the continental atmosphere, but never precipitates. Precipitation on land $P$ (set to $100 \%$ ) is composed of moisture evaporated from the ocean $P_{\mathrm{o}}$ and a recycled part $P_{\mathrm{c}}$. On the land surface, water runs off $Q$, or evaporates through direct evaporation $E_{\mathrm{i}}$ or through transpiration $E_{\mathrm{t}}$. Part of this evaporation is lost to the ocean $E_{\mathrm{O}}$, while other parts of the evaporation recycle $E_{\mathrm{c}, \mathrm{i}}$ and $E_{\mathrm{c}, \mathrm{t}}$. Evaporation data are from STEAM (Part 1), precipitation data are from ERA-I, the recycled fractions and lifetimes are calculated by WAM-2layers (Appendix B), and the other terms follow from the water balance. Symbols are further explained in Sects. 2.2.1 and 3.1.

interception, and transpiration. They show the fraction of atmospheric moisture originating from terrestrial evaporation, i.e. interception and transpiration respectively, averaged for each day (actual model time step is $15 \mathrm{~min}$ ) and clearly show the seasonality of moisture recycling. As a sidenote, some differences in patterns between Fig. 2a and van der Ent et al. (2010, Fig. 3) are caused by the inclusion of the second layer in our atmospheric moisture tracking method. For example, the higher precipitation recycling values in North America are likely caused by the inclusion of fast recycling, while the lower values along the coast of western Africa and the southeastern coast of South America are likely caused by accounting for vertically sheared winds. These findings are similar to those of Goessling and Reick (2013, Fig. 6).

Precipitation recycling due to transpiration shows higher values (Fig. 2c) and is in the absolute sense more important than interception (Fig. 2b). Although the patterns of Fig. 2b and $\mathrm{c}$ are very similar, there are a few noteworthy differences, for which we can think of two reasons: first, dominance of one type of evaporative flux in a certain area and, second,
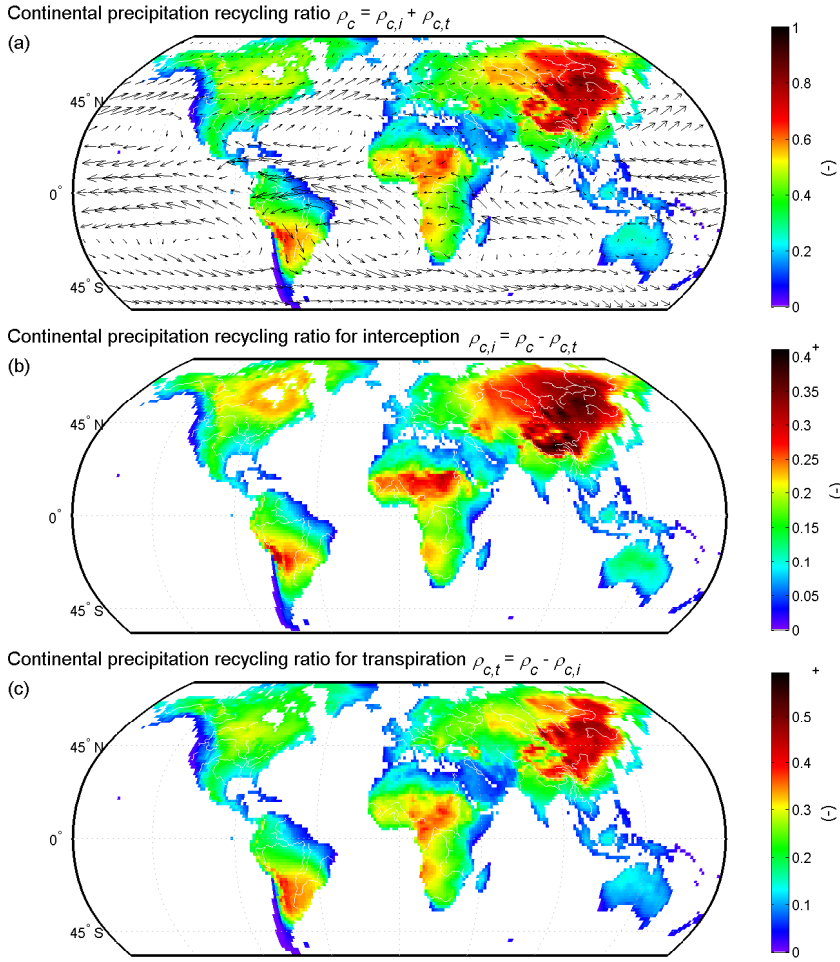

Figure 2. Continental precipitation recycling (1999-2008). (a) Continental precipitation recycling ratio $\rho_{\mathrm{c}}$, (b) continental precipitation recycling ratio for interception $\rho_{\mathrm{c}, \mathrm{i}}$, and (c) continental precipitation recycling ratio for transpiration $\rho_{\mathrm{c}, \mathrm{t}}$. The colour scale of (b) ends at 0.41 , which is the global average fraction of direct evaporative fluxes (interception); the colour scale of (c) ends at 0.59, which is the global average fraction of delayed evaporative flux (transpiration). The arrows in (a) indicate the vertically integrated moisture fluxes.

dominance of one type of evaporative flux during a certain part of the year with different prevailing winds. For example, in South America, the hot spot of interception recycling is situated more to the north compared to the hot spot of transpiration recycling. This is explained by high interception in the Amazonian rainforest (Fig. A1b), compared to transpiration being high throughout the continent (Fig. A1c), and by transpiration being more dominant during winter when the atmospheric flow is more directed to the south (Fig. A2).

The complementary process of precipitation recycling is evaporation recycling. The different metrics corresponding to evaporation recycling (Eqs. 7 to 11) are shown in Fig. 3. Regions with high evaporation recycling (i.e. high ratio and substantial evaporation) are important source regions for sustaining downwind precipitation. Figure $3 \mathrm{a}$ and c contain information about where the respective evaporative fluxes are important as well as to which regions they supply the moisture. The sum of Fig. 3a and c leads to Fig. 3e. The evaporation recycling efficiencies (Fig. $3 b$ and d) just contain information about the likelihood of a particle to recycle after 
Continental evaporation recycling ratio for interception $\varepsilon_{c, i}=\varepsilon_{c}-\varepsilon_{c, t}$

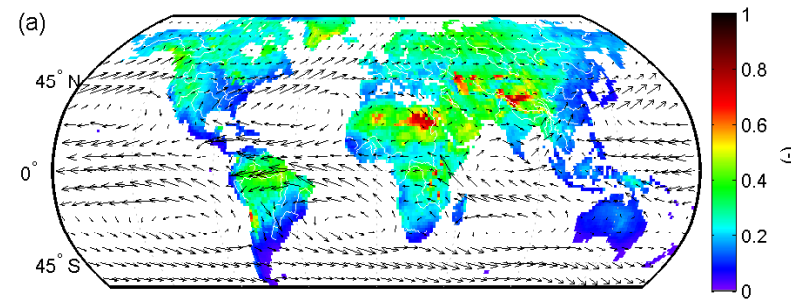

Continental evaporation recycling ratio for transpiration $\varepsilon_{c, t}=\varepsilon_{c}-\varepsilon_{c, i}$

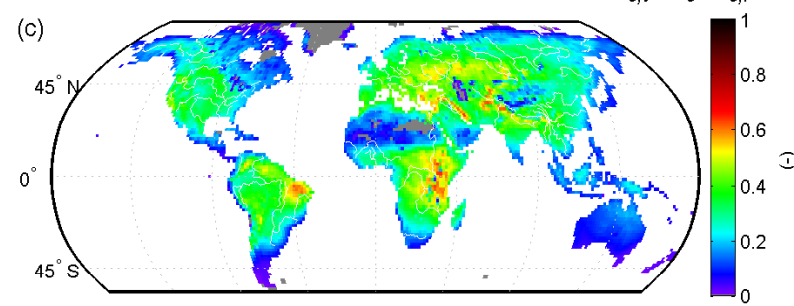

Continental evaporation recycling ratio $\varepsilon_{c}=\varepsilon_{c . l}+\varepsilon_{c . t}$

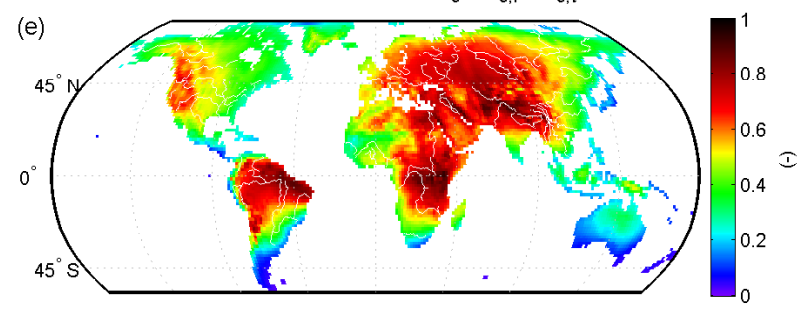

Continental evaporation recycling efficiency for interception $\varepsilon_{c, i i}$

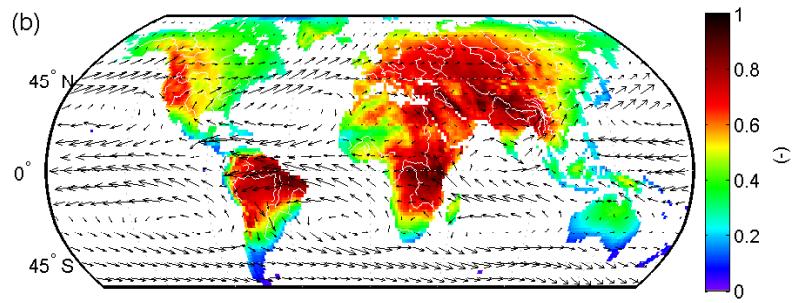

Continental evaporation recycling efficiency for transpiration $\varepsilon_{c, t t}$

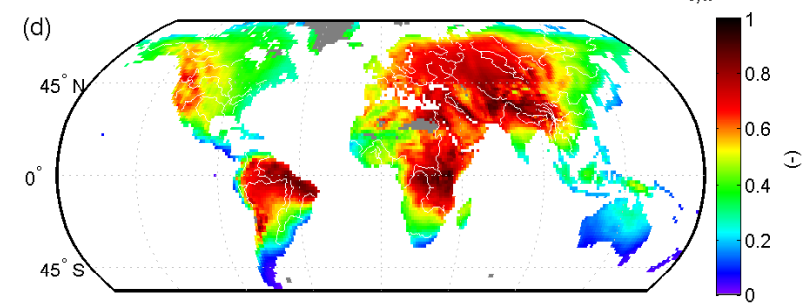

$\varepsilon_{c . i i}-\varepsilon_{c . t t}$

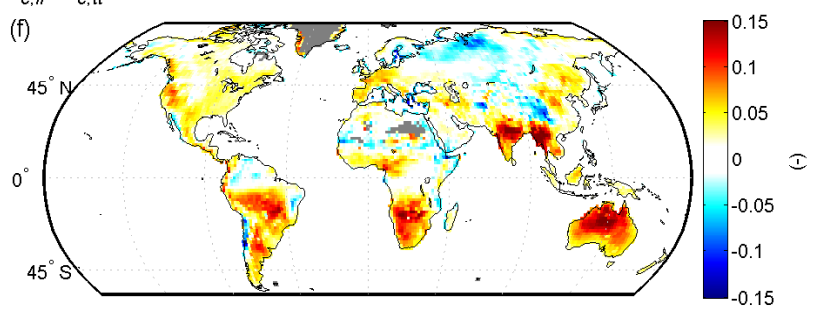

Figure 3. Continental evaporation recycling (1999-2008). (a) Continental evaporation recycling ratio for interception $\varepsilon_{\mathrm{c}, \mathrm{i}}$, (b) continental evaporation recycling efficiency for interception $\varepsilon_{\mathrm{c}, \mathrm{ii}}$, (c) continental evaporation recycling ratio for transpiration $\varepsilon_{\mathrm{c}, \mathrm{t}}$, (d) continental evaporation recycling efficiency for transpiration $\varepsilon_{\mathrm{c}, \mathrm{tt}}$, (e) continental evaporation recycling ratio $\varepsilon_{\mathrm{c}}$, and (f) $\varepsilon_{\mathrm{c}, \mathrm{ii}}-\varepsilon_{\mathrm{c}, \mathrm{tt}}$. Grey values on land indicate no data, due to the fact that the evaporative flux in question is 0 . The arrows in (a) and (b) indicate the vertically integrated moisture fluxes.

continental evaporation. From Fig. $3 \mathrm{f}$ it can be seen that in most regions of the world interception evaporation (Figs. 3b and $\mathrm{A} 1 \mathrm{~b}$ ) is more likely to return as precipitation over land than transpiration (Figs. 3d and A1c). This is especially the case in regions with a relatively small continental mass (in relation to the prevalent winds) and distinct wet and dry seasons, such as southern Africa, India, and Australia, where transpiration in the dry season is relatively likely to return to the ocean (see also the seasonal differences in moisture recycling metrics in Sect. 3.5).

In the Congo and northern Amazon regions, the continental evaporation recycling efficiencies are high (Fig. 3b and d) and the differences between relative interception and transpiration recycling are practically zero (Fig. 3f), which indicates that, independent of the type of evaporation process, each water particle is equally likely to return to the continent. This indicates strong local recycling, or at least evaporative fluxes that contribute to precipitation elsewhere on the continent, throughout the year. However, Fig. $3 \mathrm{f}$ also indicates some regions in Eurasia where transpiration is more likely to return to the continent (in blue). This can probably be explained by the fact that in these areas almost all evaporation in winter comes from interception (Fig. A2c), which, for the most part, is subsequently advected over and away from the relatively dry continent (Fig. A2a). In other words, the moisture coming from interception has less opportunity to recycle, whereas transpiration is present only in the wetter summer season and has more opportunity to recycle (see also the seasonal differences in moisture recycling metrics in Sect. 3.5).

\subsection{Atmospheric lifetime of recycled moisture}

Figure 4 shows the time spent in the atmosphere by the moisture that recycles over land. Figure $4 \mathrm{a}$ indicates the time that continentally evaporated moisture has spent in the atmosphere until it precipitates (Eq. 12). In other words, it is the time component of Fig. 2a. Note that in places where $\rho_{\mathrm{c}}$ (Fig. 2a) is low the corresponding regions in Fig. 4a contain little information. Figure 4b (Eq. 13) and c (Eq. 14) indicate the time it takes before direct (interception, soil moisture, and inland waters) and delayed (transpiration) evaporative fluxes return to the terrestrial land surface.

Figure $4 \mathrm{~b}$ and $\mathrm{c}$ are the time components of Fig. $3 \mathrm{~b}$ and d. We can see that in general the direct evaporative fluxes (Fig. 4b) remain in the atmosphere for a shorter period of 


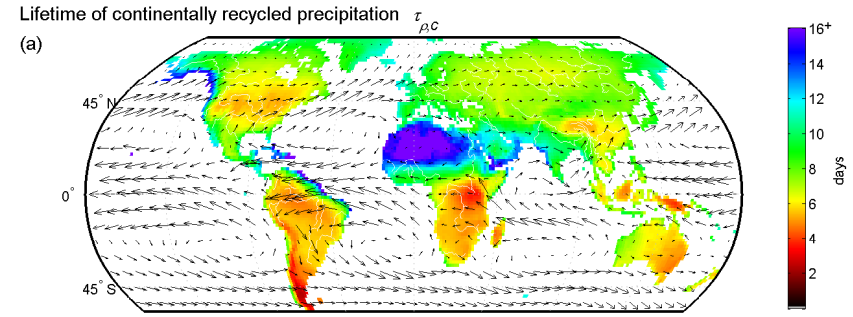

Lifetime of the interception that recycles on land $\tau_{\varepsilon, \mathrm{c}, i}$

(b)

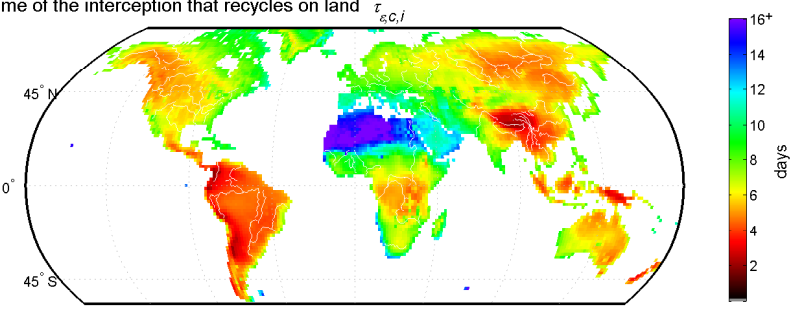

Lifetime of the transpiration that recycles on land $\tau_{\varepsilon, C, t}$

(c)

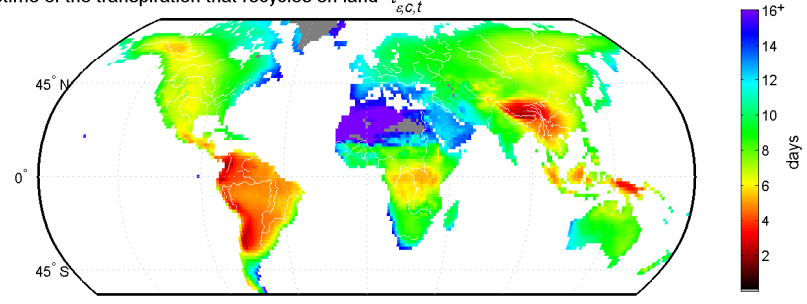

Figure 4. Average atmospheric lifetimes of recycled moisture (1999-2008). (a) Lifetime of continentally recycled precipitation $\tau_{\rho, \mathrm{c}}$ (defined at the point of precipitation), (b) lifetime of the interception that recycles on land $\tau_{\varepsilon, \mathrm{c}, \mathrm{i}}$ (defined at the point of evaporation), and (c) lifetime of the transpiration that recycles on land $\tau_{\varepsilon, \mathrm{c}, \mathrm{t}}$ (defined at the point of evaporation). Grey values on land indicate no data, due to the fact that the evaporative flux in question is 0 . The arrows in (a) indicate the vertically integrated moisture fluxes.

time compared to transpiration (Fig. 4c). We can explain this by the fact that the terrestrial timescales of the direct evaporative fluxes are much shorter than those of transpiration (Part 1, Figs. 9 to 11). The differences between Fig. 4b and $\mathrm{c}$ are less strong in the very wet tropical regions around the Equator, as well as in the Andes and Himalayas. This is probably caused by the absence of distinctively different precipitation-triggering mechanisms throughout the year. On the other hand, we see several regions where the atmospheric lifetime of interception recycling (Fig. 4b) is much lower than that of transpiration recycling (Fig. 4c). Many of these regions correspond to those identified in Fig. $3 \mathrm{f}$ (e.g. southern Africa, India, and Australia). However, in contrast to Fig. 3f, the lifetime of interception recycling is also shorter in northern Eurasia, which is probably due to the fact that Fig. 4 just considers the recycled part of the precipitation.

Interestingly, recycled precipitation (Fig. 4a) in North America has spent less time in the atmosphere than in Eurasia. We think that this could be explained by a fraction of evaporation in North America that passes over the Atlantic Ocean in summer and precipitates in Europe, which ob-
Local length scale of precipitation reycling $\lambda_{\rho}$

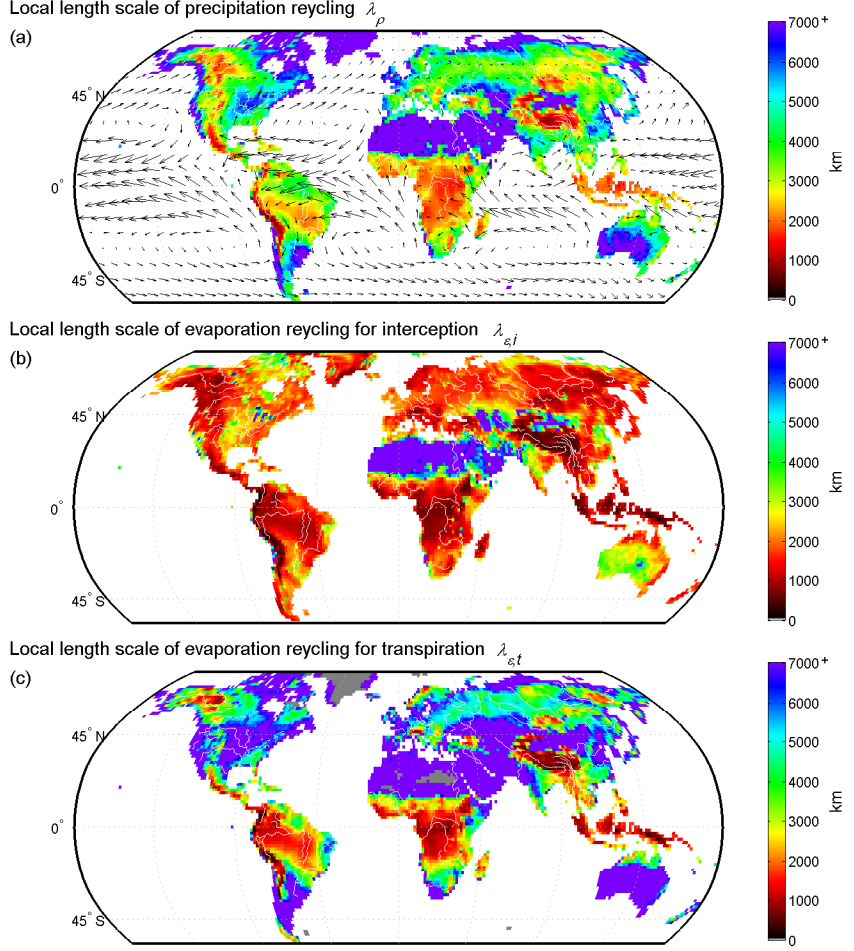

Figure 5. Local length scales of the moisture recycling process (1999-2008). (a) Length scale of precipitation recycling $\lambda_{\rho}$, (b) length scale of evaporation recycling for interception $\lambda_{\varepsilon, \mathrm{i}}$, and (c) length scale of evaporation recycling for transpiration $\lambda_{\varepsilon, t}$. Grey values on land indicate no data, due to the fact that the evaporative flux in question is 0 . Note that lower values indicate higher moisture feedback strength. The arrows in (a) indicate the moisture fluxes in the lowest part of the atmosphere (approximately the lowest $2 \mathrm{~km}$ of the atmosphere at standard pressure, Eq. B5).

viously increases the average atmospheric residence time. This phenomenon can also be observed from animations 2 and 3 (Supplement). It seems that transpiration (animation 3 and Fig. 4c) is a slightly larger contributor to this crosscontinental transport than the direct evaporative fluxes (animation 2 and Fig. 4b).

\subsection{Local length scales of moisture recycling}

We assess local moisture recycling strength using local length scales of moisture recycling (Eqs. 19 to 28), which are a scale- and shape-independent alternative to the oftenused regional recycling ratios (Eqs. 17 and 18) (see also van der Ent and Savenije, 2011, Fig. 2). Figure 5a shows the local length scale of precipitation recycling, where the importance of local evaporation for precipitation is indicated by a lower value. Note that the arrows in the graph now indicate the moisture fluxes in the bottom part of the atmosphere only (Eq. B5) as this is where the fast recycling takes place. If the values are similar over a large area, the local length scale is also a proxy for travel distance (e.g. $\sim 2000 \mathrm{~km}$ in 
sub-Saharan Africa), despite a possible underestimation due to local moisture not reaching the fast-moving, upper layers of the atmosphere. The precipitation recycling length scale is generally low in the wet tropical regions, but increases with strong winds, such as is the case in the northern Amazon and eastern Africa (Fig. 5a). Low length scales are also present in mountainous regions (e.g. Rocky Mountains, Andes, Alps, Caucasus, and Tibetan Plateau) and areas of weak winds (e.g. throughout Russia).

Figure $5 \mathrm{~b}$ and $\mathrm{c}$ show the length scales of evaporation recycling for interception and transpiration respectively. They provide a proxy for the distance an evaporated water particle travels before returning to the land surface. In the world's deserts there is obviously very little precipitation, and the probability of an evaporated particle returning locally is very low given the high local length scales. Ignoring the deserts, Fig. $5 \mathrm{~b}$ indicates that direct evaporation on most of the globe has a length scale of less than $2500 \mathrm{~km}$ (this corresponds to $\sim 2 \%$ recycling within $100 \mathrm{~km}$ ).

We have already seen that interception in general has a higher probability to recycle over land (Figs. 1 and 3) and returns to the land surface more quickly (Figs. 1 and 4). Consistent with this, the length scale of interception recycling (Fig. 5b) is much shorter compared to that of transpiration recycling (Fig. 5c). The difference in length scales between interception and transpiration is quite striking, especially in the temperate zones. This is similar to the finding in Fig. 4, but seems more pronounced. The typical timescale of a wet spell is 1-5 days (Zolina et al., 2013), while evaporation from interception has a timescale at the surface of the order of hours (Part 1, Figs. 9c and d and 10c and d) and transpiration has a timescale of the order of weeks to months (Part 1, Figs. 9a and 10a). Since interception takes place only during wet spells and transpiration takes place regardless, it follows that interception recycling is much more local than transpiration recycling. During wet and dry seasons similar contrasting roles of interception and transpiration are expected, which we will investigate in the next section.

\subsection{Seasonality of moisture recycling metrics}

A selection of moisture recycling metrics for the months of January and July is shown in Fig. 6. In summer, the land is warmer than the ocean and continental precipitation recycling ratios are higher, whereas is winter this is the opposite (Fig. 6a-d). Looking at the Northern Hemisphere's temperate and polar climate zones, the lifetimes and length scales in winter (Fig. 6e, g, i and k) are in most places shorter than in summer (Fig. $6 f, h, j$ and 1 ). This means that evaporation in winter generally returns to the land surface more quickly than in summer. However, evaporation in winter is much lower (Fig. A2) and is thus a less important contributor to precipitation than in summer (Fig. 6a-d). In the tropics and subtropics, the moisture recycling metrics are driven more by monsoonal periods, with stronger feedback, i.e. shorter atmospheric lifetimes (Fig. 6e-h) and shorter length scales (Fig. 6i-1) during the monsoon season.

The different roles of interception and transpiration in the hydrological cycle become evident when we compare January and July (Fig. 6), relative to the annual averages (Figs. 2 to 5). For example, it is clear that, in the Northern Hemisphere's temperate and polar zones in January, evaporation from interception is the principal moisture recycling mechanism (Fig. 6a vs. c, and Fig. 6i vs. k). This is explained by the near absence of transpiration (Fig. A2e). However, near absence of transpiration is not a necessity for interception to be the principal recycling mechanism, which we can see from Australia and South Africa in January (summer). This is probably explained by the relatively small dimensions of these land masses, which cause transpiration outside of a wet spell to be advected to the oceanic atmosphere more often than evaporated interception.

Whereas transpiration can compensate for a reduction of interception in the wet season, the opposite is not true, making transpiration-dependent regions more vulnerable. For example, coastal western Africa in January and the La Plata basin (rivers contributing to the bay bordering Argentina and Uruguay) in July are predominantly dependent on recycled moisture from transpiration. For both these regions, this transpiration recycling dependence is in a period with little rainfall (Fig. A2a and b). However, this rainfall could be important for dry season farming and drinking water supply, making these regions susceptible to local and remote land-use changes. These regions are particularly threatened by upwind deforestation, which could therefore lead to reduced precipitation in western Africa and the La Plata basin in general, but particularly during their respective dry seasons.

Observations already show a general decrease (with some edge effects) in precipitation over forest-to-non-forest transitions due to deforestation in the Amazon basin (Knox et al., 2011). Our results suggest that reduced moisture recycling could propagate the decline in precipitation further downwind. Bagley et al. (2014) showed how the northern part of the Amazon, which is wet all year round, depends on recycled moisture and as such is vulnerable to deforestation as well. Our results suggest that deforestation in this northern part would mainly lead to reduced interception recycling. Potentially, other evaporative fluxes may compensate for the reduction in interception evaporation (Part 1, Table 5), and other well-managed vegetation would not necessarily lead to dramatic rainfall reductions. For the southern part of the Amazon and the link with the La Plata basin, however, deforestation could be a much bigger problem, as reduced transpiration recycling could lead to a drier dry season. It must be noted, however, that the magnitude of the reduced moisture recycling effect depends on the land use that replaces the forest. Irrigated agriculture or open water could theoretically maintain high evaporation rates as well, but most other landuse types would not be able to produce high evaporation rates during the dry season. 
Continental precipitation recycling ratio for interception $\rho_{C, j}$ in January

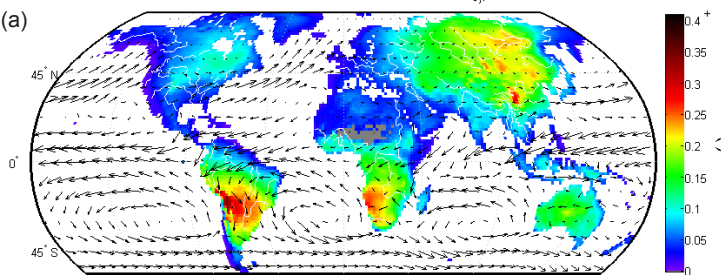

Continental precipitation recycling ratio for transpiration $\rho$ in January

(c)

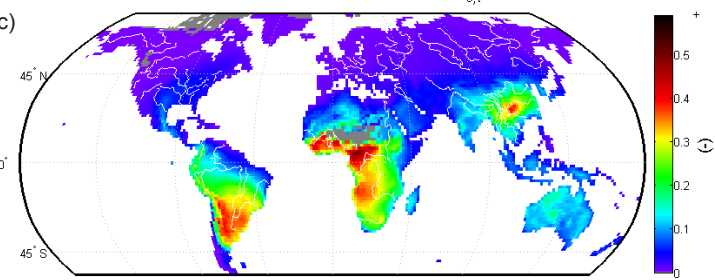

Atmospheric lifetime of the interception that recycles on land $\tau_{\varepsilon, C, j}$ in January (e)

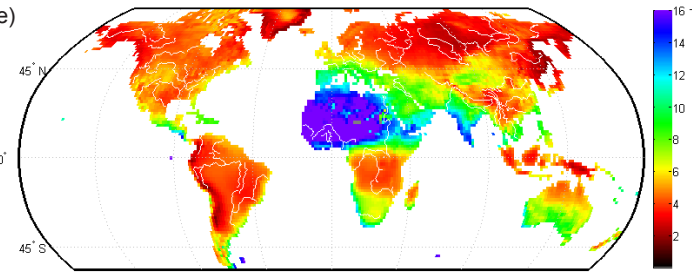

Atmospheric lifetime of the transpiration that recycles on land $\tau_{\varepsilon C, t}$ in January

(g)

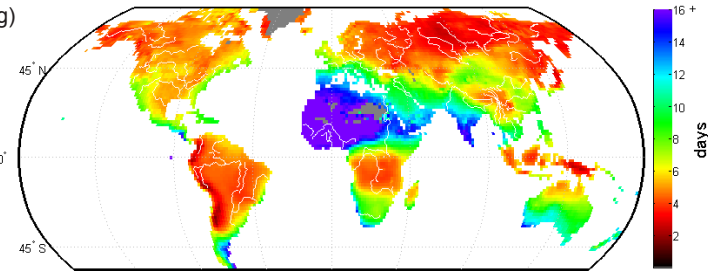

Local length scale of evaporation reycling for interception $\lambda_{\varepsilon, j}$ in January

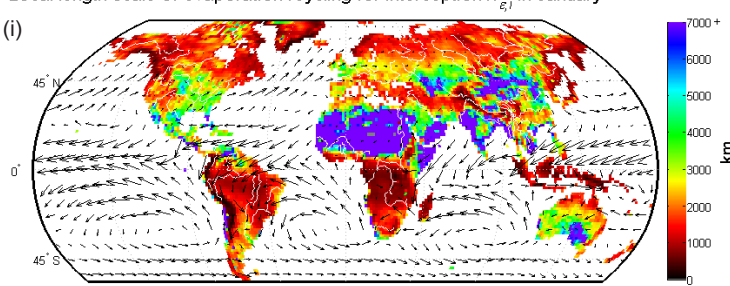

Local length scale of evaporation reycling for transpiration $\lambda_{\varepsilon f}$ in January

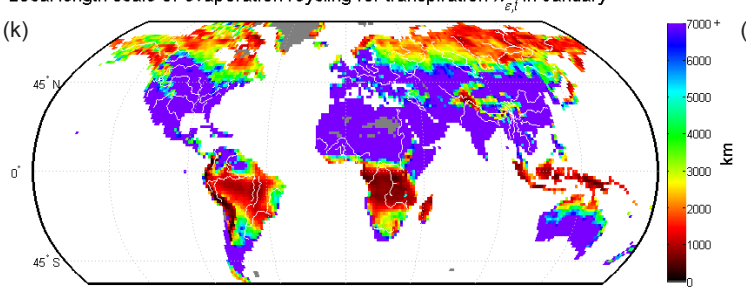

Continental precipitation recycling ratio for interception $\rho_{c, i}$ in July

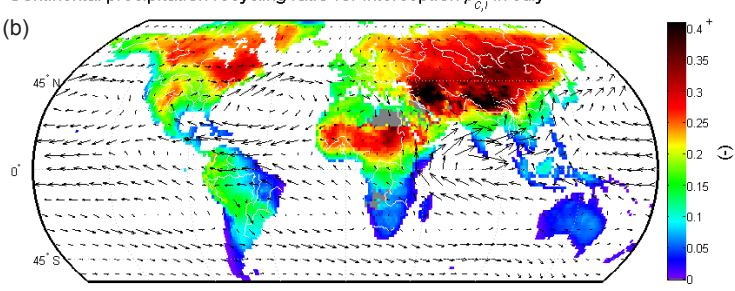

Continental precipitation recycling ratio for transpiration $\rho_{c, t}$ in July
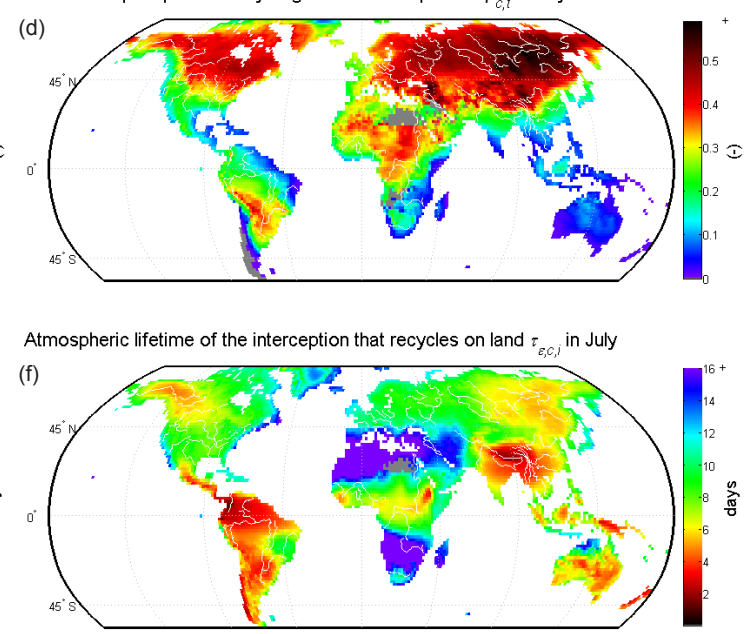

Atmospheric lifetime of the transpiration that recycles on land $\tau_{\varepsilon c, t}$ in July

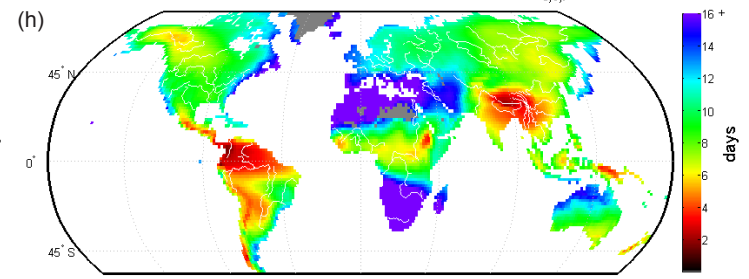

Local length scale of evaporation reycling for interception $\lambda_{g i}$ in July

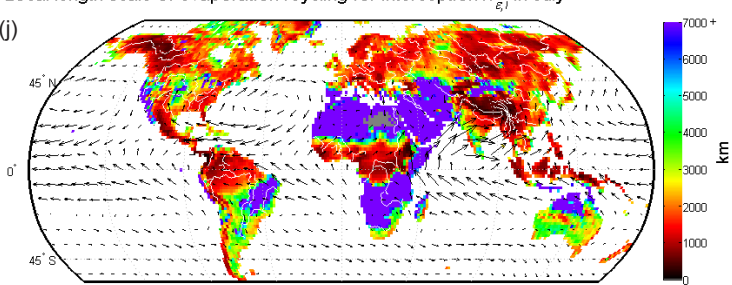

Local length scale of evaporation reycling for transpiration $\lambda_{f f}$ in July

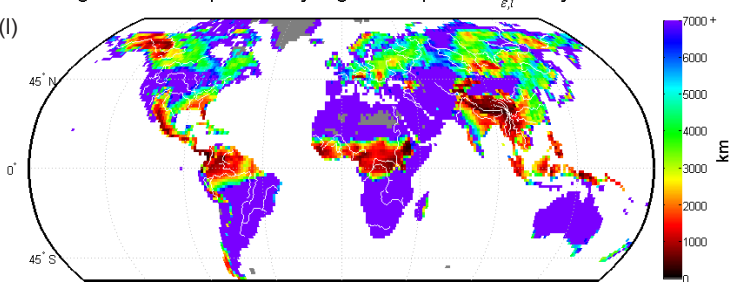

Figure 6. Moisture recycling metrics for January (left column) and July (right column). The arrows in (a) and (b) indicate the vertically integrated moisture fluxes, which are most relevant for panels $(\mathbf{a}-\mathbf{h})$. The arrows in (i) and (j) indicate the moisture flux only in approximately the lowest $2 \mathrm{~km}$ of the atmosphere, which is most relevant for panels (i-l). 
Table 2. Global differences in moisture recycling behaviour for direct evaporation (mostly interception) and transpiration for different evaporation data.

\begin{tabular}{lrrr}
\hline & Default & Transpiration-plus & Interception-plus \\
\hline STEAM change & & & \\
\hline Interception storage capacity & $100 \%$ & $50 \%$ & $150 \%$ \\
Unsaturated zone storage capacity & $100 \%$ & $120 \%$ & $80 \%$ \\
\hline STEAM output & & & \\
\hline Total evaporation $E$ & 73900 & 73200 & 74200 \\
$E_{\mathrm{i}} / E$ & $\mathrm{~km}^{3} \mathrm{year}^{-1}$ & $\mathrm{~km}^{3} \mathrm{year}^{-1}$ & $\mathrm{~km}^{3} \mathrm{year}^{-1}$ \\
$E_{\mathrm{t}} / E$ & $41 \%$ & $36 \%$ & $46 \%$ \\
\hline Global average results & $59 \%$ & $64 \%$ & $54 \%$ \\
\hline$\varepsilon_{\mathrm{c}, \mathrm{ii}}$ & & & \\
$\varepsilon_{\mathrm{c}, \mathrm{tt}}$ & $60 \%$ & $60 \%$ & $60 \%$ \\
Atmospheric lifetime of $E_{\mathrm{i}}$ & $56 \%$ & $57 \%$ & $56 \%$ \\
Atmospheric lifetime of $E_{\mathrm{t}}$ & 8.1 days & 8.2 days & 8.0 days \\
$\tau_{\varepsilon, \mathrm{c}, \mathrm{i}}$ & 9.1 days & 9.1 days & 9.1 days \\
$\tau_{\varepsilon, \mathrm{c}, \mathrm{t}}$ & 5.9 days & 6.0 days & 5.8 days \\
& 6.8 days & 6.8 days & 6.8 days \\
\hline
\end{tabular}

\subsection{Robustness of the results}

We can conclude from the previous results that the roles of interception and transpiration for moisture recycling are different due to the fact that they have different magnitudes during wet and dry spells, and due to the fact that they are dominant during different seasons. However, the question could be raised of whether the different moisture recycling characteristics for interception and transpiration would also be true if other partitioned evaporation were used as input data. Therefore, we repeated our moisture recycling analysis with two different input data sets: one where the parameterisation of STEAM favours more transpiration, and another where the parameterisation favours interception (Part 1, Table 5). The effects on the moisture recycling efficiency and the residence times for $E_{\mathrm{i}}$ and $E_{\mathrm{t}}$ are shown in Table 2. It can be seen that the results are not very sensitive to the parameterisation. The efficiencies of interception and transpiration are almost the same for each of the scenarios. The residence time in the atmosphere of (recycled) direct evaporation in the interception-plus scenario is slightly lower than in the default scenario. This is probably explained by the fact that in the interception-plus scenario $E_{\mathrm{i}}$ consists to a greater extent of vegetation interception, which is the fastest feedback process (Part 1, Table 5 and Fig. 11). The opposite is the case for the transpiration-plus scenario. Overall, the differences between the scenarios are minor, and thus we consider the moisture recycling differences found for interception and transpiration to be robust results.

\section{Summary, conclusions and outlook}

The objective of this paper was to assess the role of the different components of evaporation in the hydrological cycle over continents. We have used the atmospheric moisture tracking model WAM-2layers to track direct (purely physical) and delayed (biophysical) evaporative fluxes, as computed by STEAM (Part 1). By direct evaporative fluxes we mean the water evaporated from vegetation interception, floor interception, soil moisture, and inland waters. Interception is what largely dominates direct evaporation (Part 1, Fig. 2). By delayed evaporative flux we mean transpiration.

We summarise our findings about the different roles of interception and transpiration in the hydrological cycle as follows: (1) $60 \%$ of direct evaporation returns to the land surface, whereas this is $56 \%$, and thus slightly less, for transpiration; (2) the residence time of direct evaporation in the atmosphere is 8 days ( 6 for the recycling part only) and 9 days for transpiration; and (3) the local length scale of interception recycling is on average much shorter than the length scale of transpiration recycling. We attribute these results to the fact that interception has a small storage reservoir and therefore occurs mostly during wet spells. Transpiration, on the other hand, draws from a large storage reservoir and can occur during dry periods, when evaporated moisture is more likely to be advected over large distances, as well.

Therefore, the results found are particularly useful from a landscape resilience perspective. Regions that receive precipitation from continentally recycled evaporation are vulnerable to upwind land-use changes. However, a region that receives precipitation originating from interception is more resilient to land-use changes in their source region than 
a region that depends on transpiration. A land-use change could for example reduce interception capacity, but during a wet period this is likely to be compensated by other evaporative fluxes. Regions that receive precipitation from continentally recycled transpiration are less resilient to land-use changes in their source region, especially if a region's precipitation depends on transpiration in the dry season. This is because, when vegetation is removed, the mechanism to retain and draw moisture from the root zone is lost as well, and total evaporation will be significantly reduced.

Our results suggest that the effect of land-use change on moisture recycling is very different during wet and dry seasons, and also during summer and winter, indicating that seasonality is important to consider when analysing effects of land-use change. During the wet season, increased or decreased interception could amplify or attenuate the local moisture recycling signal. Still, we conclude that land-use change needs to be drastic to influence the evaporative fluxes in a way that this signal would have continental-scale influence. During the dry season, land-use change (in particular deforestation) could lead to reduced transpiration, which reduces moisture recycling, and as such could have a domino effect on precipitation downwind. Such potential effects of forest-to-agriculture conversion make the already challenging task of sustainably producing enough food for a growing population (Rockström et al., 2012) even more challenging. On the other hand, moisture-recycling-dependent regions such as western Africa could potentially benefit from increased rainfall due to large-scale implementations of water harvesting, small reservoirs, and agroforestry (Reij and Smaling, 2008; van de Giesen et al., 2010) not only in western Africa itself but also in central Africa (upwind).
For future studies, we expect that coupled land-biosphereatmosphere models will be increasingly used for predicting climate impacts due to land-use changes. However, we must not forget the tremendous uncertainty in the process understanding and parameterisation underlying these models (e.g. Pielke Sr et al., 2011). It is not uncommon for different models to predict different outputs for temperature (e.g. Brovkin et al., 2013), and especially precipitation (e.g. Pitman et al., 2012), and fundamental issues are still debated, such as the partitioning of evaporation (Jasechko et al., 2013; CoendersGerrits et al., 2014). Another issue requiring attention is that recent studies have shown that increased atmospheric carbon dioxide reduces transpiration (De Boer et al., 2011; Keenan et al., 2013). Our paper shows that this will likely reduce moisture recycling and precipitation in some regions (see Figs. 1c, 2c and $d$ and $6 c$ and d), making them more vulnerable to droughts, but this clearly needs more quantification.

This paper stresses the fact that the land surface has a large potential to influence the hydrological cycle. Quantification of exact regional and planetary boundaries (Rockström et al., 2009) of tolerable land-use changes before drastic precipitation changes are expected is, however, difficult to provide. This is because our results only allow for a first-order estimate of land-use change impacts, whereas very drastic land-use change affects the energy balance and wind patterns as well (e.g. Kleidon et al., 2000; Roy and Avissar, 2002; Dallmeyer and Claussen, 2011; Goessling and Reick, 2011; Bowring et al., 2014). Nonetheless, we anticipate that our results may help future coupled land-atmosphere research to interpret whether the findings are the result of moisture recycling or other climatic processes. As such, we hope that this paper is useful for providing a larger context to future regional studies examining the impact of land-use changes on the hydrological cycle. 


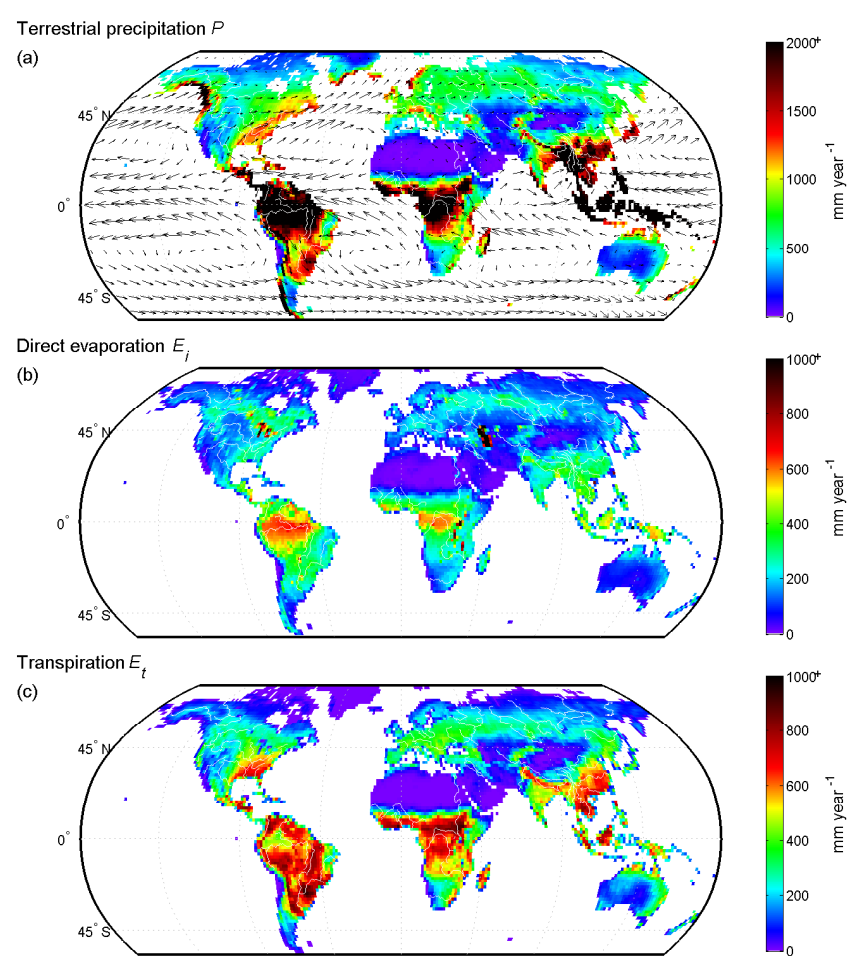

Figure A1. Average continental precipitation and evaporative fluxes (1999-2008). (a) Precipitation; (b) direct evaporative flux, dominated by interception (Eq. 2); and (c) delayed evaporative flux, i.e. transpiration (Eq. 3). The arrows in (a) indicate the vertically integrated moisture fluxes.

\section{Appendix A: Precipitation and partitioned evaporation}

In this appendix we present figures of global precipitation (ERA-I) and partitioned evaporation (STEAM) (Eqs. 1 to 3). Figure A1 presents the annual averages, which are relevant for interpreting Figs. 2 to 5, while Fig. A2 presents the January and July figures, relevant for interpreting Fig. 6.

\section{Appendix B: Atmospheric moisture tracking (WAM-2layers)}

Here, we present our atmospheric moisture tracking model WAM-2layers V2.3.01. This is an update to the previously used WAM-1layer (van der Ent et al., 2010; Keys et al., 2012; van der Ent and Savenije, 2013), the key difference being the addition of a second atmospheric layer instead of merely having one layer. The horizontal moisture transport with two layers (and vertical exchange between them) is more realistic than moisture tracking with vertically integrated moisture fluxes. It was shown that WAM-2layers arrived at very similar results to those from a highly detailed, complex moisture tracking scheme in a regional climate model (Knoche and Kunstmann, 2013), but with much smaller computational cost (van der Ent et al., 2013). In this paper we extend WAM2layers to track tagged moisture on the global scale forward and backward in time.

\section{B1 Water balance}

The underlying principle of WAM-2layers is the water balance:

$$
\begin{aligned}
\frac{\partial S_{k}}{\partial t} & =\frac{\partial\left(S_{k} u\right)}{\partial x}+\frac{\partial\left(S_{k} v\right)}{\partial y}+E_{\mathrm{i}, k}+E_{\mathrm{t}, k}-P_{k}+\xi_{k} \\
& \pm F_{\mathrm{v}}\left[\mathrm{L}^{3} \mathrm{~T}^{-1}\right],
\end{aligned}
$$

where $S_{k}$ is the atmospheric moisture storage (i.e. precipitable water) in layer $k$ (either the top or the bottom layer), $t$ is time, $u$ and $v$ stand for the wind components in $x$ (zonal) and $y$ (meridional) direction respectively, $\xi$ is a residual, and $F_{\mathrm{v}}$ is the vertical moisture transport. We calculate moisture transport over the boundaries of the grid cells. Change in atmospheric moisture due to horizontal transport is described by

$\frac{\Delta(S u)}{\Delta x}=F_{k, x}^{-}-F_{k, x}^{+}$

and

$\frac{\Delta(S v)}{\Delta y}=F_{k, y}^{-}-F_{k, y}^{+}$,

where $F_{k}$ is the moisture flux over the boundary of a grid cell in the bottom or top layer. Superscript "_" stands for the western and southern boundaries of the grid cell, and "+" stands for the eastern and northern boundaries. The moisture flux can be calculated as follows:

$F_{k}=\frac{L}{g \rho_{\mathrm{w}}} \int_{p_{\text {top }}}^{p_{\text {bottom }}} q u_{\mathrm{h}} \mathrm{d} p$,

where $L$ is the length of the grid cell perpendicular to the direction of the moisture flux, $g$ is the gravitational acceleration, $\rho_{\mathrm{w}}$ the density of liquid water $\left(1000 \mathrm{~kg} \mathrm{~m}^{-3}\right), p$ stands for pressure, $q$ stands for specific humidity, and $u_{\mathrm{h}}$ is the horizontal component in either $x$ or $y$ direction. For the top layer the following applies: $p_{\text {top }}=0$ and $p_{\text {bottom }}=p_{\text {divide }}$. For the bottom layer the following applies: $p_{\text {top }}=p_{\text {divide }}$ and $p_{\text {bottom }}=p_{\text {surface }}$. Here, $p_{\text {divide }}$ is the pressure at the division between the bottom and top layer. Given the ERA-I data in this paper, we calculated $p_{\text {divide }}$ by

$p_{\text {divide }}=7438.803+0.728786 \times p_{\text {surface }}(\mathrm{Pa})$,

which corresponds to $81283 \mathrm{~Pa}$ at a standard surface pressure of $101325 \mathrm{~Pa}$. By trial-and-error investigation, this division appeared to best capture the division between sheared wind systems, where wind in the bottom layer goes in a different 
Terrestrial precipitation $P$ in January

(a)

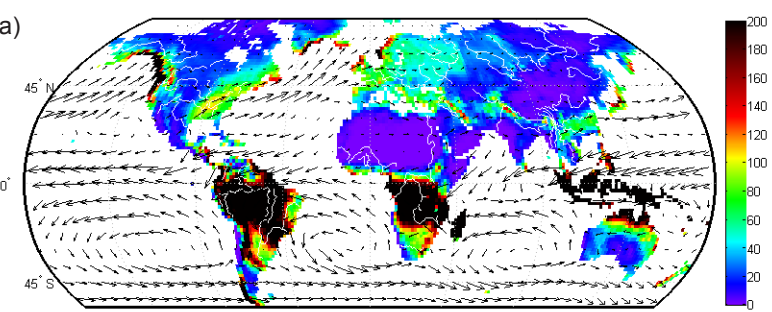

Direct evaporation $E$ in January

(c)

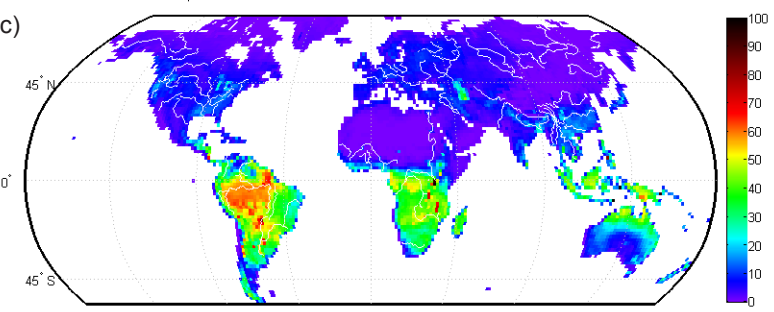

ranspiration $E$ in January

(e)

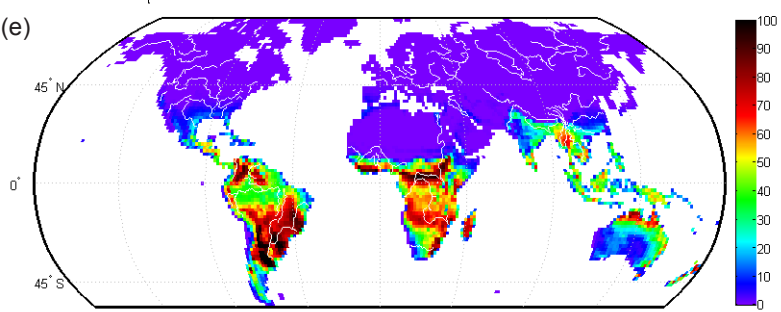

Terrestrial precipitation $P$ in July

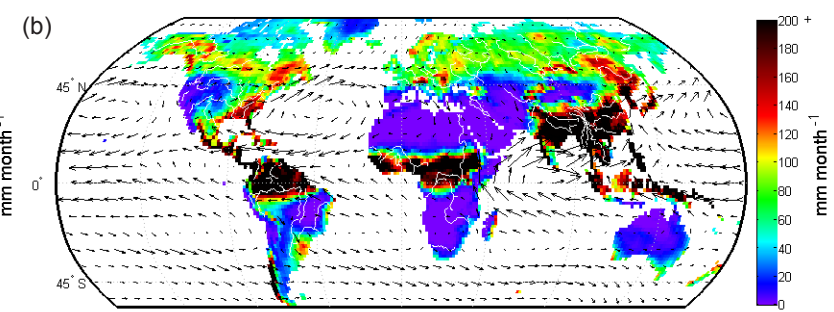

Direct evaporation $E$ in July

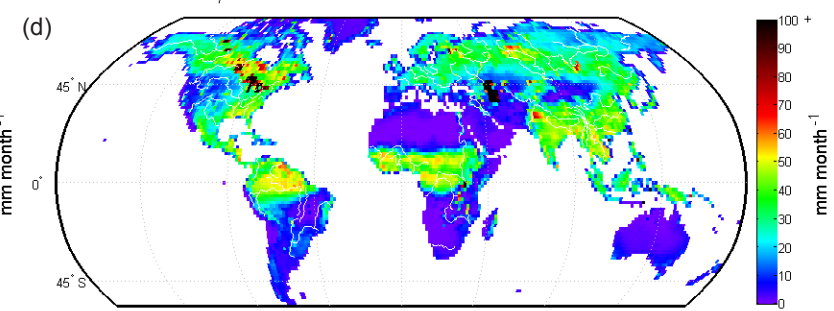

Transpiration $E_{f}$ in July

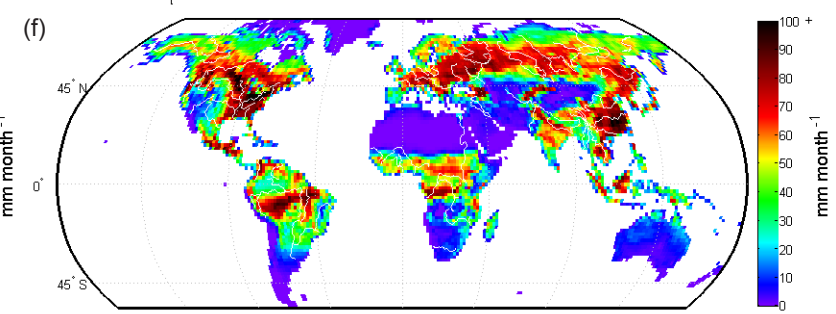

Figure A2. Precipitation and evaporative fluxes for January (left column) and July (right column).

direction to wind in the top layer. Over land, the bottom layer roughly accounts for $40-80 \%$ of the total column moisture storage and for 30-70\% of the total horizontal moisture flux.

Looking further at Eq. (B1), the evaporation from interception and transpiration $E_{\mathrm{i}}$ and $E_{\mathrm{t}}$ (together $E$ ) enter only in the bottom layer; thus $E_{k}=E$ in the bottom layer, and $E_{k}=0$ in the top layer. Precipitation is assumed to be immediately removed from the moisture storage (i.e. no exchange of falling precipitation between the top and bottom layer), and we assume "well-mixed" conditions for precipitation:

$P_{k}=P \frac{S_{k}}{S}$,

where $P$ is total precipitation and $S$ is total atmospheric storage in the vertical. The residual $\xi$ is the result of data assimilation in the ERA-I data and the fact that our offline tracking scheme calculates the water balance on a coarser spatial and temporal resolution.

The vertical transport of moisture $F_{\mathrm{V}}$ in Eq. (B1) is difficult to calculate because, besides transport by average vertical wind speed, there is dispersive moisture exchange due to the convective scheme in ERA-I. Therefore, we assume the vertical exchange to be the closure term of our water balance. However, as a result of the residual $\xi$, we cannot always fully close the water balance. Hence, closure here is defined by the ratio of residuals in the top and bottom layer being proportional to the moisture content of the layers:

$\frac{\xi_{\text {top }}}{S_{\text {top }}}=\frac{\xi_{\text {bottom }}}{S_{\text {bottom }}}$.

Using Eq. (B7), vertical moisture transport can be calculated as follows:

$F_{\mathrm{v}}=\frac{S_{\text {bottom }}}{S}\left(\xi_{\text {bottom }}^{*}+\xi_{\text {top }}^{*}\right)-\xi_{\text {bottom }}^{*}$,

where $\xi_{\text {bottom }}^{*}$ and $\xi_{\text {top }}^{*}$ are the residuals before vertical transport was taken into account. Note that including $F_{\mathrm{V}}$ (positive downward), as calculated by Eq. (B8), in Eq. (B1) will lead to Eq. (B7) being satisfied.

\section{B2 Water tagging experiments}

In WAM-2layers we apply the same water balance as in Eq. (B1) on moisture of a certain origin. For example, the water balance of tagged interception (denoted by subscript i) in the bottom layer of the atmosphere for forward tracking is 
described by

$$
\begin{aligned}
\frac{\partial S_{\mathrm{i}, \text { bottom }}}{\partial t} & =\frac{\partial\left(S_{\mathrm{i}, \text { bottom }} u\right)}{\partial x}+\frac{\partial\left(S_{\mathrm{i}, \text { bottom }} v\right)}{\partial y}+E_{\mathrm{i}} \\
& -P_{\mathrm{i}} \pm F_{\mathrm{v}, \mathrm{i}} .
\end{aligned}
$$

Equations that are similar to Eq. (B9) apply to tagged transpiration, the top layer, and backward tracking. These equations are solved using an explicit numerical scheme on Eulerian coordinates (the same as the input data). The time step of the calculation is, however, reduced to $0.25 \mathrm{~h}$ for reasons of numerical stability. By trial and error we found that the vertical flux as calculated by Eq. (B8) was too small to adequately take care of the vertical transport of tagged water (bottom/top bucket completely filled, with the other bucket being nearly empty). We attribute this to turbulent moisture exchange (especially during rain events) between the top and bottom layer. To solve this we have retained $F_{\mathrm{v}}$ as the net vertical moisture flux, but during the tagging experiments we used a vertical flux of $4 F_{\mathrm{v}}$ in the direction of the net flux and $3 F_{\mathrm{v}}$ in the opposite direction. We acknowledge that this is a simplification of the turbulent moisture exchange, but we consider this is an adequate parameterisation for our purposes. Moreover, our results were not found to be very sensitive to the turbulent moisture exchange. Different forward and backward tagging runs with WAM-2layers allowed for the computation of the continental moisture recycling metrics presented in Sect. 2.2.1.

\section{B3 Water age tagging experiments}

We are also interested in the time that evaporated moisture from interception and transpiration spends in the atmosphere. Therefore, we have introduced a tracer that keeps track of the age of the atmospheric moisture in the forward tagging runs. This age increases linearly with time, and at each time step $t$ the model calculates the age $N_{\mathrm{g}}$ of the tagged moisture present at that location according to the following formula:

$N_{\mathrm{g}}(t)=\left(\begin{array}{l}S_{\mathrm{g}}(t-1)\left(N_{\mathrm{g}}(t-1)+\Delta t\right) \\ +\sum F_{\mathrm{g}}^{\text {in }} \Delta t\left(N_{\mathrm{g}}^{\text {in }}(t-1)+\Delta t\right) \\ -\sum F_{\mathrm{g}}^{\text {out }} \Delta t\left(N_{\mathrm{g}}(t-1)+\Delta t\right) \\ -P_{\mathrm{g}} \Delta t\left(N_{\mathrm{g}}(t-1)+\Delta t\right)+E_{\mathrm{g}} \Delta t \frac{\Delta t}{2}\end{array}\right) / S_{\mathrm{g}}(t)$,

where the subscript $\mathrm{g}$ stands for tagged water, which in the experiments of this paper is either interception of transpiration. These age tagging experiments allowed for the computation of the atmospheric residence times of precipitated and evaporated moisture (Sect. 2.2.2).

\section{B4 Recycling length scale calculations}

To be able to calculate the length scales of evaporation $\lambda_{\varepsilon, \mathrm{i}}$ and $\lambda_{\varepsilon, \mathrm{t}}$ (Eqs. 27 and 28), we need the regional evaporation recycling ratios $\varepsilon_{\mathrm{r}, \mathrm{i}}$ and $\varepsilon_{\mathrm{r}, \mathrm{t}}$. We derived these ratios for each $1.5^{\circ}$ latitude $\times 1.5^{\circ}$ longitude grid cell by performing a special water tagging run. In this run we compute for all grid cells at once the moisture that originated from the "home" grid cell. We assumed horizontal moisture transport of tagged water out of a grid cell did not to return anymore to this grid cell. This also means that these runs can be performed with larger time steps, which was indeed confirmed by several tests in which the results were found to be insensitive to the chosen time step. The tagged precipitation originating from and returning to the same grid cell $P_{\mathrm{r}}$ is assumed to be equal to the tagged regional evaporation $E_{\mathrm{r}}$ (see Eqs. 15 and 16). However, this is not really the same due to the residence time of water in the atmosphere, but it is not likely to be dramatically different. Furthermore, we need a representative value for the distance $\Delta x$ the water travels in a grid cell. Following van der Ent and Savenije (2011), we approximate this as follows:

$$
\Delta x=L_{x} \frac{\bar{F}_{\text {bottom }, x}}{\bar{F}_{\text {bottom }, x}+\bar{F}_{\text {bottom }, y}}+L_{y} \frac{\bar{F}_{\text {bottom }, y}}{\bar{F}_{\text {bottom }, x}+\bar{F}_{\text {bottom }, y}},
$$

where $L_{x}$ and $L_{y}$ are the lengths of a grid cell in zonal and meridional direction respectively. Note that the moisture fluxes in the bottom layer are used because this is where virtually all of the regional (grid cell)-scale recycling takes place. 


\section{The Supplement related to this article is available online at doi:10.5194/esd-5-471-2014-supplement.}

Acknowledgements. R. J. van der Ent and H. H. G. Savenije did this work as part of the research programme Division for Earth and Life Sciences (ALW), which is financed by the Netherlands Organisation for Scientific Research (NWO). L. Wang-Erlandsson and P. W. Keys did this work as part of a grant from the Swedish Research Council, Vetenskapsrådet. We thank Helge Goessling; two anonymous referee; and the editor, Stefan Dekker, for their useful comments that helped to improve this manuscript.

Edited by: S. Dekker

\section{References}

Bagley, J. E., Desai, A. R., Dirmeyer, P. A., and Foley, J. A.: Effects of land cover change on moisture availability and potential crop yield in the world's breadbaskets, Environ. Res. Lett., 7, 014009 , doi:10.1088/1748-9326/7/1/014009, 2012.

Bagley, J. E., Desai, A. R., Harding, K. J., Snyder, P. K., and Foley, J. A.: Drought and deforestation: has land cover change influenced recent precipitation extremes in the Amazon?, J. Climate, 27, 345-361, doi:10.1175/jcli-d-12-00369.1, 2014.

Bosilovich, M. G. and Schubert, S. D.: Water vapor tracers as diagnostics of the regional hydrologic cycle, J. Hydrometeorol., 3, 149-165, doi:10.1175/15257541(2002)003<0149:WVTADO>2.0.CO;2, 2002.

Bosilovich, M. G., Sud, Y., Schubert, S. D., and Walker, G. K.: GEWEX CSE sources of precipitation using GCM water vapor tracers, GEWEX News, 12 pp. (1, 6, 7, 12), 2002.

Bowring, S. P. K., Miller, L. M., Ganzeveld, L., and Kleidon, A.: Applying the concept of "energy return on investment" to desert greening of the Sahara/Sahel using a global climate model, Earth Syst. Dynam., 5, 43-53, doi:10.5194/esd-5-43-2014, 2014.

Brovkin, V., Boysen, L., Arora, V. K., Boisier, J. P., Cadule, P., Chini, L., Claussen, M., Friedlingstein, P., Gayler, V., Van den Hurk, B. J. J. M., Hurtt, G. C., Jones, C. D., Kato, E., de NobletDucoudré, N., Pacifico, F., Pongratz, J., and Weiss, M.: Effect of anthropogenic land-use and land-cover changes on climate and land carbon storage in CMIP5 projections for the twentyfirst century, J. Climate, 26, 6859-6881, doi:10.1175/jcli-d-1200623.1, 2013.

Brubaker, K. L., Entekhabi, D., and Eagleson, P. S.: Estimation of continental precipitation recycling, J. Climate, 6, 1077-1089, doi:10.1175/1520-0442(1993)006<1077:EOCPR>2.0.CO;2, 1993.

Burde, G. I. and Zangvil, A.: The estimation of regional precipitation recycling, Part I: Review of recycling models, J. Climate, 14, 2497-2508, doi:10.1175/15200442(2001)014<2497:TEORPR>2.0.CO;2, 2001.

Chahine, M. T.: The hydrological cycle and its influence on climate, Nature, 359, 373-380, doi:10.1038/359373a0, 1992.

Coenders-Gerrits, A. M. J., van der Ent, R. J., Bogaard, T. A., Wang-Erlandsson, L., Hrachowitz, M., and Savenije, H. H. G.:
Uncertainties in transpiration estimates, Nature, 506, E1-E2, doi:10.1038/nature12925, 2014.

Corless, R. M., Gonnet, G. H., Hare, D. E. G., Jeffrey, D. J., and Knuth, D. E.: On the Lambert W function, Adv. Comput. Math., 5, 329-359, 1996.

Dallmeyer, A. and Claussen, M.: The influence of land cover change in the Asian monsoon region on present-day and midHolocene climate, Biogeosci., 8, 1499-1519, doi:10.5194/bg-81499-2011, 2011.

De Boer, H. J., Lammertsma, E. I., Wagner-Cremer, F., Dilcher, D. L., Wassen, M. J., and Dekker, S. C.: Climate forcing due to optimization of maximal leaf conductance in subtropical vegetation under rising $\mathrm{CO}_{2}$, P. Natl. Acad. Sci. USA, 108, 4041-4046, doi:10.1073/pnas.1100555108, 2011.

Dee, D. P., Uppala, S. M., Simmons, A. J., Berrisford, P., Poli, P., Kobayashi, S., Andrae, U., Balmaseda, M. A., Balsamo, G., Bauer, P., Bechtold, P., Beljaars, A. C. M., Van de Berg, L., Bidlot, J., Bormann, N., Delsol, C., Dragani, R., Fuentes, M., Geer, A. J., Haimberger, L., Healy, S. B., Hersbach, H., Hòlm, E. V., Isaksen, L., Kållberg, P., Köhler, M., Matricardi, M., McNally, A. P., Monge-Sanz, B. M., Morcrette, J. J., Park, B. K., Peubey, C., de Rosnay, P., Tavolato, C., Thépaut, J. N., and Vitart, F.: The ERA-Interim reanalysis: configuration and performance of the data assimilation system, Q. J. Roy. Meteor. Soc., 137, 553-597, doi:10.1002/qj.828, 2011.

Dekker, S. C., Rietkerk, M., and Bierkens, M. F. P.: Coupling microscale vegetation-soil water and macroscale vegetationprecipitation feedbacks in semiarid ecosystems, Glob. Change Biol., 13, 671-678, doi:10.1111/j.1365-2486.2007.01327.x, 2007.

Dirmeyer, P. A. and Brubaker, K. L.: Contrasting evaporative moisture sources during the drought of 1988 and the flood of 1993, J. Geophys. Res., 104, 19383-19397, doi:10.1029/1999JD900222, 1999.

Dirmeyer, P. A. and Brubaker, K. L.: Characterization of the global hydrologic cycle from a back-trajectory analysis of atmospheric water vapor, J. Hydrometeorol., 8, 20-37, doi:10.1175/JHM557.1, 2007.

Dirmeyer, P. A., Brubaker, K. L., and DelSole, T.: Import and export of atmospheric water vapor between nations, J. Hydrol., 365, 11 22, doi:10.1016/j.jhydrol.2008.11.016, 2009.

Dirmeyer, P. A., Wei, J., Bosilovich, M. G., and Mocko, D. M.: Comparing Evaporative Sources of Terrestrial Precipitation and Their Extremes in MERRA Using Relative Entropy, J. Hydrometeorol., 15, 102-116, doi:10.1175/jhm-d-13-053.1, 2014.

Dominguez, F. and Kumar, P.: Precipitation recycling variability and ecoclimatological stability - a study using NARR Data, Part I: Central US plains ecoregion, J. Climate, 21, 5165-5186, doi:10.1175/2008JCLI1756.1, 2008.

Dominguez, F., Kumar, P., Liang, X. Z., and Ting, M.: Impact of atmospheric moisture storage on precipitation recycling, J. Climate, 19, 1513-1530, doi:10.1175/JCLI3691.1, 2006.

Druyan, L. M. and Koster, R. D.: Sources of Sahel precipitation for simulated drought and rainy seasons, J. Climate, 2, 1438-1446, doi:10.1175/1520-0442(1989)002<1438:SOSPFS>2.0.CO;2, 1989.

Eltahir, E. A. B. and Bras, R. L.: Precipitation recycling in the Amazon Basin, Q. J. Roy. Meteor. Soc., 120, 861-880, doi:10.1002/qj.49712051806, 1994. 
Froehlich, K., Gibson, J. J., and Aggarwal, P.: Deuterium Excess in Precipitation and Its Climatological Significance, International Atomic Energy Agency, C\&S Papers Series 13/P, 54-66, Vienna, Austria, 2001.

Gat, J. R. and Matsui, E.: Atmospheric water balance in the Amazon basin: an isotopic evapotranspiration model, J. Geophys. Res., 96, 13179-13188, doi:10.1029/91jd00054, 1991.

Gimeno, L., Stohl, A., Trigo, R. M., Dominguez, F., Yoshimura, K., Yu, L., Drumond, A., Durán-Quesada, A. M., and Nieto, R.: Oceanic and terrestrial sources of continental precipitation, Rev. Geophys., 50, RG4003, doi:10.1029/2012RG000389, 2012.

Goessling, H. F. and Reick, C. H.: What do moisture recycling estimates tell us? Exploring the extreme case of nonevaporating continents, Hydrol. Earth Syst. Sci., 15, 3217-3235, doi:10.5194/hess-15-3217-2011, 2011.

Goessling, H. F. and Reick, C. H.: On the "well-mixed" assumption and numerical 2-D tracing of atmospheric moisture, Atmos. Chem. Phys., 13, 5567-5585, doi:10.5194/acp-13-55672013, 2013.

Gong, C. and Eltahir, E.: Sources of moisture for rainfall in west Africa, Water Resour. Res., 32, 3115-3121, doi:10.1029/96WR01940, 1996.

Henderson-Sellers, A., McGuffie, K., and Zhang, H.: Stable isotopes as validation tools for global climate model predictions of the impact of Amazonian deforestation, J. Climate, 15, 2664-2677, doi:10.1175/15200442(2002)015<2664:SIAVTF>2.0.CO\%3B2, 2002.

Jasechko, S., Sharp, Z. D., Gibson, J. J., Birks, S. J., Yi, Y., and Fawcett, P. J.: Terrestrial water fluxes dominated by transpiration, Nature, 496, 347-350, doi:10.1038/nature11983, 2013.

Keenan, T. F., Hollinger, D. Y., Bohrer, G., Dragoni, D., Munger, J. W., Schmid, H. P., and Richardson, A. D.: Increase in forest water-use efficiency as atmospheric carbon dioxide concentrations rise, Nature, 499, 324-327, doi:10.1038/nature12291, 2013.

Keys, P. W., van der Ent, R. J., Gordon, L. J., Hoff, H., Nikoli, R., and Savenije, H. H. G.: Analyzing precipitationsheds to understand the vulnerability of rainfall dependent regions, Biogeosci., 9, 733-746, doi:10.5194/bg-9-733-2012, 2012.

Keys, P. W., Barnes, E. A., van der Ent, R. J., and Gordon, L. J.: Variability of moisture recycling using a precipitationshed framework, Hydrol. Earth Syst. Sci., 18, 3937-3950, doi:10.5194/hess-18-3937-2014, 2014.

Kleidon, A., Fraedrich, K., and Heimann, M.: A green planet versus a desert world: estimating the maximum effect of vegetation on the land surface climate, Clim. Change, 44, 471-493, doi:10.1023/a:1005559518889, 2000.

Knoche, H. R. and Kunstmann, H.: Tracking atmospheric water pathways by direct evaporation tagging: a case study for West Africa, J. Geophys. Res., 118, 12345-12358, doi:10.1002/2013JD019976, 2013.

Knox, R., Bisht, G., Wang, J., and Bras, R.: Precipitation variability over the forest-to-nonforest transition in southwestern Amazonia, J. Climate, 24, 2368-2377, doi:10.1175/2010jcli3815.1, 2011.

Koster, R., Jouzel, J., Suozzo, R., Russell, G., Broecker, W., Rind, D., and Eagleson, P.: Global sources of local precipitation as determined by the NASA/GISS GCM, Geophys. Res. Lett., 13, 121-124, doi:10.1029/GL013i002p00121, 1986.
Koster, R. D., Dirmeyer, P. A., Guo, Z., Bonan, G., Chan, E., Cox, P., Gordon, C. T., Kanae, S., Kowalczyk, E., Lawrence, D., Liu, P., Lu, C. H., Malyshev, S., McAvaney, B., Mitchell, K., Mocko, D., Oki, T., Oleson, K., Pitman, A., Sud, Y. C., Taylor, C. M., Verseghy, D., Vasic, R., Xue, Y., and Yamada, T.: Regions of strong coupling between soil moisture and precipitation, Science, 305, 1138-1140, doi:10.1126/science.1100217, 2004.

Kurita, N., Yoshida, N., Inoue, G., and Chayanova, E. A.: Modern isotope climatology of Russia: a first assessment, J. Geophys. Res., 109, D03102, doi:10.1029/2003jd003404, 2004.

Lettau, H., Lettau, K., and Molion, L. C.: Amazonia's hydrological cycle and the role of atmospheric recycling in assessing deforestation effects, Mon. Weather Rev., 107, 227-238, doi:10.1175/1520-0493(1979)107<0227:AHCATR>2.0.CO;2, 1979.

Lorenz, C. and Kunstmann, H.: The hydrological cycle in three state-of-the-art reanalyses: intercomparison and performance analysis, J. Hydrometeorol., 13, 1397-1420, doi:10.1175/jhm-d11-088.1, 2012.

Mueller, B., Hirschi, M., Jimenez, C., Ciais, P., Dirmeyer, P. A., Dolman, A. J., Fisher, J. B., Jung, M., Ludwig, F., Maignan, F., Miralles, D. G., McCabe, M. F., Reichstein, M., Sheffield, J., Wang, K., Wood, E. F., Zhang, Y., and Seneviratne, S. I.: Benchmark products for land evapotranspiration: LandFlux-EVAL multi-data set synthesis, Hydrol. Earth Syst. Sci., 17, 3707-3720, doi:10.5194/hess-17-3707-2013, 2013.

Nieto, R., Gimeno, L., and Trigo, R. M.: A Lagrangian identification of major sources of Sahel moisture, Geophys. Res. Lett., 33, L18707, doi:10.1029/2006GL027232, 2006.

Numaguti, A.: Origin and recycling processes of precipitating water over the Eurasian continent: experiments using an atmospheric general circulation model, J. Geophys. Res., 104, 1957-1972, doi:10.1029/1998JD200026, 1999.

Pielke Sr, R. A., Pitman, A., Niyogi, D., Mahmood, R., McAlpine, C., Hossain, F., Goldewijk, K. K., Nair, U., Betts, R., Fall, S., Reichstein, M., Kabat, P., and de Noblet, N.: Land use/land cover changes and climate: modeling analysis and observational evidence, Wiley Interdisciplinary Reviews: Climate Change, 2, 828-850, doi:10.1002/wcc.144, 2011.

Pitman, A. J., de Noblet-Ducoudré, N., Avila, F. B., Alexander, L. V., Boisier, J.-P., Brovkin, V., Delire, C., Cruz, F., Donat, M. G., Gayler, V., Van den Hurk, B., Reick, C., and Voldoire, A.: Effects of land cover change on temperature and rainfall extremes in multi-model ensemble simulations, Earth Syst. Dynam., 3, 213-231, doi:10.5194/esd-3-213-2012, 2012.

Reij, C. P. and Smaling, E. M. A.: Analyzing successes in agriculture and land management in Sub-Saharan Africa: is macro-level gloom obscuring positive micro-level change?, Land Use Pol., 25, 410-420, 2008.

Rios-Entenza, A. and Miguez-Macho, G.: Moisture recycling and the maximum of precipitation in spring in the Iberian Peninsula, Clim. Dynam., 42, 3207-3231, doi:10.1007/s00382-013-1971-x, 2013.

Risi, C., Noone, D., Frankenberg, C., and Worden, J.: The role of continental recycling in intra-seasonal variations of continental moisture as deduced from model simulations and water vapor isotopic measurements, Water Resour. Res., 49, 4136-4156, doi:10.1002/wrcr.20312, 2013. 
Rockström, J., Steffen, W., Noone, K., Persson, A., Chapin III, F. S., Lambin, E., Lenton, T. M., Scheffer, M., Folke, C., Schellnhuber, H. J., Nykvist, B., de Wit, C. A., Hughes, T., Van der Leeuw, S., Rodhe, H., Sörlin, S., Snyder, P. K., Costanza, R., Svedin, U., Falkenmark, M., Karlberg, L., Corell, R. W., Fabry, V. J., Hansen, J., Walker, B., Liverman, D., Richardson, K., Crutzen, P., and Foley, J.: Planetary boundaries: exploring the safe operating space for humanity, Ecol. Soc., 14, 32, 33 pp., 2009.

Rockström, J., Falkenmark, M., Lannerstad, M., and Karlberg, L.: The planetary water drama: dual task of feeding humanity and curbing climate change, Geophys. Res. Lett., 39, L15401, doi:10.1029/2012g1051688, 2012.

Rowell, D. P.: The impact of Mediterranean SSTs on the Sahelian rainfall season, J. Climate, 16, 849-862, doi:10.1175/15200442(2003)016<0849:tiomso>2.0.co;2, 2003.

Roy, S. B. and Avissar, R.: Impact of land use/land cover change on regional hydrometeorology in Amazonia, J. Geophys. Res., 107, LBA 4-1-LBA 4-12, doi:10.1029/2000jd000266, 2002.

Savenije, H. H. G.: New definitions for moisture recycling and the relationship with land-use changes in the Sahel, J. Hydrol., 167, 57-78, doi:10.1016/0022-1694(94)02632-L, 1995.

Savenije, H. H. G.: The importance of interception and why we should delete the term evapotranspiration from our vocabulary, Hydrol. Process., 18, 1507-1511, doi:10.1002/hyp.5563, 2004.

Spracklen, D. V., Arnold, S. R., and Taylor, C. M.: Observations of increased tropical rainfall preceded by air passage over forests, Nature, 489, 282-285, doi:10.1038/nature11390, 2012.

Taylor, C. M., Gounou, A., Guichard, F., Harris, P. P., Ellis, R. J., Couvreux, F., and De Kauwe, M.: Frequency of Sahelian storm initiation enhanced over mesoscale soil-moisture patterns, Nat. Geosci., 4, 430-433, doi:10.1038/ngeo1173, 2011.

Tian, L., Yao, T., MacClune, K., White, J. W. C., Schilla, A., Vaughn, B., Vachon, R., and Ichiyanagi, K.: Stable isotopic variations in west China: a consideration of moisture sources, J. Geophys. Res., 112, D10112, doi:10.1029/2006JD007718, 2007.

Trenberth, K. E.: Atmospheric moisture residence times and cycling: implications for rainfall rates and climate change, Clim. Change, 39, 667-694, 1998.

Trenberth, K. E.: Atmospheric moisture recycling: role of advection and local evaporation, J. Climate, 12, 1368-1381, doi:10.1175/1520-0442(1999)012<1368:AMRROA>2.0.CO;2, 1999.

Trenberth, K. E., Fasullo, J. T., and Mackaro, J.: Atmospheric moisture transports from ocean to land and global energy flows in reanalyses, J. Climate, 24, 4907-4924, doi:10.1175/2011jcli4171.1, 2011.
Tuinenburg, O. A., Hutjes, R. W. A., and Kabat, P.: The fate of evaporated water from the Ganges basin, J. Geophys. Res., 117, D01107, doi:10.1029/2011jd016221, 2012.

van de Giesen, N., Liebe, J., and Jung, G.: Adapting to climate change in the Volta Basin, West Africa, Curr. Sci. India, 98, 1033-1037, 2010.

van den Hurk, B. J. J. M. and van Meijgaard, E.: Diagnosing land-atmosphere interaction from a regional climate model simulation over West Africa, J. Hydrometeorol., 11, 467-481, doi:10.1175/2009jhm1173.1, 2009.

van der Ent, R. J. and Savenije, H. H. G.: Length and time scales of atmospheric moisture recycling, Atmos. Chem. Phys., 11, 18531863, doi:10.5194/acp-11-1853-2011, 2011.

van der Ent, R. J. and Savenije, H. H. G.: Oceanic sources of continental precipitation and the correlation with sea surface temperature, Water Resour. Res., 49, 3993-4004, doi:10.1002/wrcr.20296, 2013.

van der Ent, R. J., Savenije, H. H. G., Schaefli, B., and Steele-Dunne, S. C.: Origin and fate of atmospheric moisture over continents, Water Resour. Res., 46, W09525, doi:10.1029/2010WR009127, 2010.

van der Ent, R. J., Tuinenburg, O. A., Knoche, H.-R., Kunstmann, H., and Savenije, H. H. G.: Should we use a simple or complex model for moisture recycling and atmospheric moisture tracking?, Hydrol. Earth Syst. Sci., 17, 4869-4884, doi:10.5194/hess17-4869-2013, 2013..

Wang-Erlandsson, L., van der Ent, R. J., Gordon, L. J., and Savenije, H. H. G.: Contrasting roles of interception and transpiration in the hydrological cycle - Part 1: Temporal characteristics over land, Earth Syst. Dynam., 5, 441-469, doi:10.5194/esd-5-4412014, 2014.

Wei, J., Dirmeyer, P. A., Wisser, D., Bosilovich, M. G., and Mocko, D. M.: Where does the irrigation water go? An estimate of the contribution of irrigation to precipitation using MERRA, J. Hydrometeorol., 14, 275-289, doi:10.1175/jhm-d-12-079.1, 2012.

Yoshimura, K., Oki, T., Ohte, N., and Kanae, S.: Colored moisture analysis estimates of variations in 1998 Asian monsoon water sources, J. Meteorol. Soc. Jpn., 82, 1315-1329, doi:10.2151/jmsj.2004.1315, 2004.

Zolina, O., Simmer, C., Belyaev, K., Gulev, S. K., and Koltermann, P.: Changes in the duration of european wet and dry spells during the last 60 years, J. Climate, 26, 2022-2047, doi:10.1175/jcli-d-11-00498.1, 2013. 